\title{
CHANGES IN THE DISTRIBUTION OF $\delta^{13} \mathrm{C}$ OF DEEP WATER $\Sigma \mathrm{CO}_{2}$ BETWEEN THE LAST GLACIATION AND THE HOLOCENE
}

\author{
W. B. Curry \\ Department of Geology and Geophysics \\ Woods Hole Oceanographic Institution \\ Woods Hole, Massachusetts
}

J. C. Duplessy and L. D. Labeyrie

Centre des Faibles Radioactivites

Laboratoire Mixte CNRS/CEA

Domaine du CNRS

Gif-sur-Yvette, France

\section{N. J. Shackleton}

Godwin Laboratory for Quaternary Research Cambridge, England

Abstract. Carbon isotopic measurements on the benthic foraminiferal genus Cibicidoides document that mean deep ocean $\delta^{13} \mathrm{C}$ values were $0.46 \%$ lower during the last glacial maximum than during the Late Holocene. The geographic distribution of $\delta^{13} \mathrm{C}$ was altered by changes in the production rate of nutrient-depleted deep water in the North Atlantic. During the Late Holocene, North Atlantic Deep Water, with high $\delta^{13} \mathrm{C}$ values and low nutrient values, can be found throughout the Atlantic Ocean, and its effects can be traced into the southern ocean where it mixes with recirculated Pacific deep water. During the glaciation, decreased production of North Atlantic Deep Water allowed southern ocean deep water to penetrate farther into the North Atlantic and across low-latitude fracture zones into the eastern Atlantic. Mean southern ocean $\delta^{13} \mathrm{C}$ values during the glaciation are lower than both North Atlantic and Pacific $\delta^{13} \mathrm{C}$ values, suggesting that production of nutrient-depleted water occurred in both oceans during the glaciation. Enriched ${ }^{13} \mathrm{C}$ values in shallow cores within the Atlantic Ocean indicate the existence of a nutrient-depleted water mass above $2000 \mathrm{~m}$ in this ocean.

\section{INTRODUCTION}

The biological and chemical processes that fractionate carbon isotopes in the ocean provide one of the most useful tracers for reconstructing past distributions of water masses and their properties. The present distribution of $\delta^{13} \mathrm{C}$ of $\mathrm{\Sigma CO}_{2}$ reproduces the general distribution of water masses in the oceans, and the gradients in $\delta^{13} \mathrm{C}$ between locations record the net flow direction between ocean basins. Certain species of

\section{Copyright 1988}

by the American Geophysical Union

Paper number 8P0327. 0883-8305/88/008P-0327\$10.00 benthic foraminifera ( $C$. wuellerstorfi, in particular) faithfully record these gradients of $\delta^{13} \mathrm{C}$, providing the tool necessary to reconstruct the past distribution of $\delta^{13} \mathrm{C}$. In this paper, we present the $\delta^{13} \mathrm{C}$ distribution for the ocean during the last 30,000 years, and from these data determine the consequences of glacial-interglacial climate change on thermohaline circulation.

\section{$\delta^{13} C$ Distribution in the Ocean}

The distribution of $\delta^{13} \mathrm{C}$ in the ocean is controlled principally by photosynthesis and remineralization of organic carbon, and by mixing between water masses of different isotopic composition. Photosynthesis in surface water preferentially extracts ${ }^{12} \mathrm{C}$ from seawater, causing the enrichment of the surface water $\mathrm{\Sigma CO}_{2}$ in ${ }^{13} \mathrm{C}$. The value of $\delta^{13} \mathrm{C}$ in seawater, after primary producers have removed all nutrients, is controlled by the mean $\delta^{13} \mathrm{C}$ and the mean nutrient concentration of the ocean [Broecker, 1982; Broecker and Peng, 1982]. Today when all of the nutrients are stripped from the surface water, the $\mathrm{\Sigma CO}_{2}$ of the surface reservoir has lost approximately $10 \%$ of its total dissolved inorganic carbon. Since the carbon that has been removed by phytoplankton has a $\delta^{13} \mathrm{C}$ equal to approximately $-20 \%$, the surface reservoir is enriched by $2.0 \%$ over the mean $\delta^{13} \mathrm{C}$ of the deep water (Figure 1). The mean ocean $\delta^{13} \mathrm{C}$ value equals $0.0 \%$ (PDB), so the surface value today equals approximately $2.0 \%$ (PDB). Complete nutrient utilization by phytoplankton generally occurs in the warm, well stratified regions of the oceans between $30^{\circ} \mathrm{N}$ and $30^{\circ} \mathrm{S}$.

Deep water masses today form at high latitudes after physical processes have increased the surface water density and caused it to sink into the deep ocean. The initial carbon isotopic composition of the water mass, its preformed value, is determined by the extent of photosynthesis that has occurred in the seawater during its residence within the euphotic zone. Before sinking into the deep ocean, phytoplankton strip ${ }^{12} \mathrm{C}$ and 


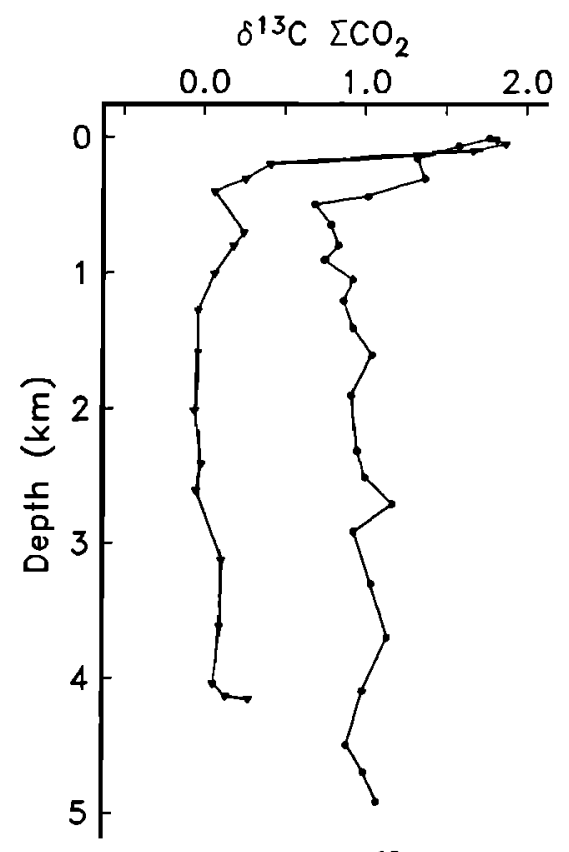

Fig. 1. The depth distribution of $\delta^{13} \mathrm{C}$ in the Pacific (triangles) and Atlantic (circles) oceans. The warm surface layers of the oceans, where stratification is strong, are generally nutrient depleted, and all surface water $\delta^{13} \mathrm{C}$ values in these regions approach $2.0 \%$ (PDB). The $\delta^{13} \mathrm{C}$ differences between the deep waters reflects the presence of nutrient-depleted, high $\delta^{13} \mathrm{C}$ deep water in the North Atlantic. Data from Kroopnick [1974, 1980].

nutrients $\left(\mathrm{PO}_{4}, \mathrm{NO}_{3}\right)$ from the surface water, enriching it in ${ }^{13} \mathrm{C}$. If the nutrient concentration is depleted to zero in the present ocean, then the preformed $\delta^{13} \mathrm{C}$ value will be near to $2.0 \%$.

At their sites of formation the principal deep water masses (North Atlantic Deep Water (NADW), Antarctic Bottom Water(AABW)) are depleted in nutrients and enriched in ${ }^{13} \mathrm{C}$ relative to mean ocean water, but their nutrient concentrations are greater than zero, and their $\delta^{13} \mathrm{C}$ values fall short of the values predicted for water stripped completely of its nutrients (Table 1). North Atlantic Deep Water is the most nutrient-depleted deep water mass forming in the oceans today. This water mass forms by the sinking of surface water in the Norwegian-Greenland Sea, mixing with Mediterranean Sea outflow and Labrador Sea water. Phosphate concentrations of these components are generally low $(<1.0 \mu \mathrm{M} / \mathrm{kg})$, and initial $\delta^{13} \mathrm{C}$ values of NADW are enriched to 1.0 to $1.4 \%$ (PDB). Antarctic Bottom Water has more $\mathrm{PO}_{4}$ at its source region than NADW, so it is generally lower in $\delta^{13} \mathrm{C}(0.3 \%$ PDB $)$.

After leaving the surface layers of the ocean, $\delta^{13} \mathrm{C}$ of deep water masses changes only through two processes: remineralization of organic carbon and mixing between water masses with different isotopic compositions. Consequently, the $\delta^{13} \mathrm{C}$ composition of seawater is not a conservative tracer of deep water masses. Within the
TABLE 1. The End-Member Values of $\delta^{13} \mathrm{C}$ and $\left[\mathrm{PO}_{4}\right]$ for North Atlantic Deep Water (NADW), Antarctic Bottom Water (AABW), and Nutrient-Depleted Surface Water (SW)

\begin{tabular}{ccc}
\hline Water Mass & $\begin{array}{c}{\left[\mathrm{PO}_{4}\right]} \\
\mu \mathrm{mole} / \mathrm{kg}\end{array}$ & $\begin{array}{c}\delta^{13} \mathrm{C} \\
\% \text { oo }(\mathrm{PDB})\end{array}$ \\
\hline NADW & 1.0 & 1.1 \\
AABW & 2.3 & 0.3 \\
SW & 0.0 & 2.0 \\
\hline
\end{tabular}

Atlantic Ocean, however, the $\delta^{13} \mathrm{C}$ distribution today is acting much like a conservative tracer because the rates of production and degradation of organic carbon are very low in this ocean. This generalization is especially true for the western basins of the Atlantic, where the effects of mixing between NADW and AABW occur as bathymetric gradients in $\delta^{13} \mathrm{C}$ at sharp water mass boundaries and as less distinct latitudinal gradients that occur in the South Atlantic as these two water masses mix and flow to the east to join and form the Circumpolar Deep Water. The mixing of these water masses is demonstrated by the straight lines on property-property diagrams of $\delta^{13} \mathrm{C}$ of $\Sigma \mathrm{CO}_{2}$ and conservative tracers such as salinity or $\delta^{18} \mathrm{O}$ of the seawater (Figure 2).

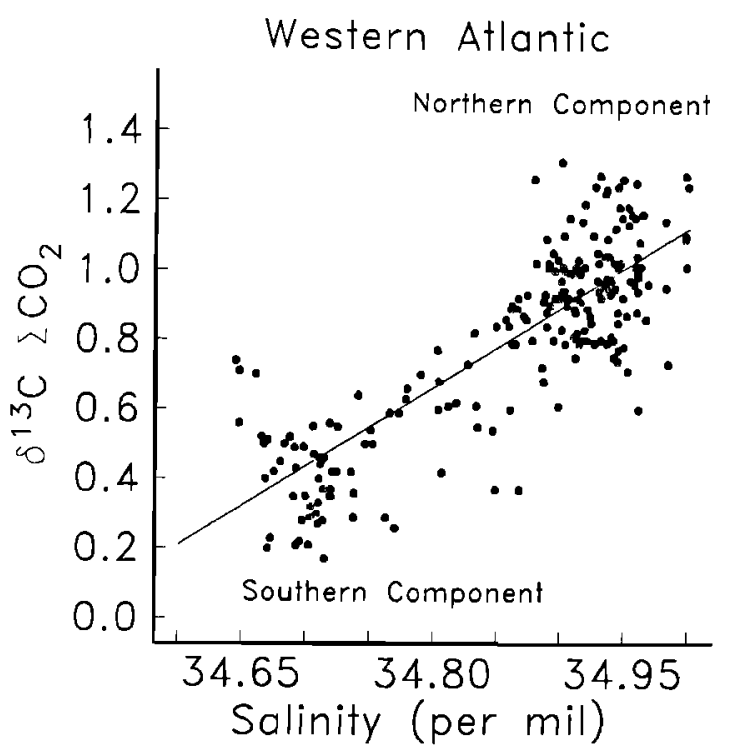

Fig. 2. The relationship between salinity and $\delta^{13} \mathrm{C}$ in the western Atlantic demonstrating the mixing of North Atlantic Deep Water (northern component) and Antarctic Bottom Water (southern component) from GEOSECS stations $\left(\delta^{13} \mathrm{C}\right.$ data from Kroopnick, [1985]). The end-member compositions of salinity and $\delta^{13} \mathrm{C}$, respectively, are $35.0 \%$ and $1.2 \%$ for NADW and $34.66 \%$ and $0.5 \%$ for AABW. 


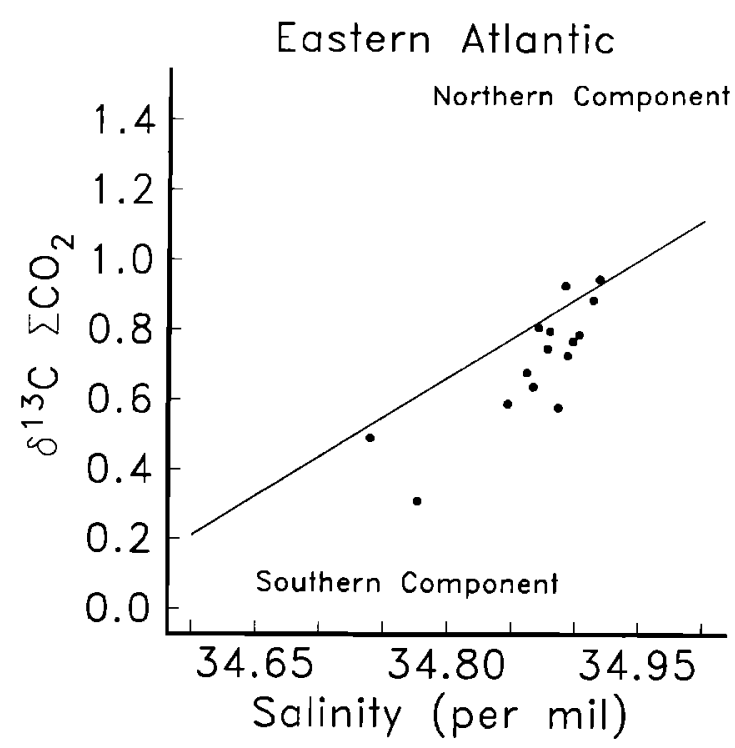

Fig. 3. The relationship between salinity and $\delta^{13} \mathrm{C}$ for eastern Atlantic locations from GEOSECS data $\left(\delta^{13} \mathrm{C}\right.$ data from Kroopnick, [1985]). For comparable mixtures of northern and southern component deep water the eastern basins are depleted in $\delta^{13} \mathrm{C}$ relative to the western basins. This difference in $\delta^{13} \mathrm{C}$ results from the isolation of the eastern Atlantic and the greater input of remineralized organic carbon. The depletion in ${ }^{13} \mathrm{C}$ is proportional to the enrichment in other nonconservative properties ([Si]), showing that both degradation of organic matter and mixing affect the $\delta^{13} \mathrm{C}$ distribution in the Atlantic.

The $\delta^{19} \mathrm{C}$ composition of deep waters is not conservative on a global scale, nor is it conservative on a ocean basin scale in regions of high productivity or within basins with long residence times. One example of the nonconservative nature of $\delta^{13} \mathrm{C}$ occurs in the eastern basins of the Atlantic Ocean, where deep water originally from the western basin is isolated and exposed to large amounts of settling particulate organic carbon (Figure 3). The $\delta^{13} \mathrm{C}$ values (and $\left[\mathrm{O}_{2}\right]$ ) of comparable water types are generally lower in the eastern Atlantic than in the western Atlantic (compare Figure 3 with Figure 2); enrichment of bioreactive constituents $\left(\mathrm{SiO}_{2}\right)$ in eastern Atlantic deep water [Broecker, 1981] are consistent with the observed decrease in $\delta^{13} \mathrm{C}$. These geochemical changes occur because of the circulation patterns in the region and the isolation of the eastern basins from the mainstream of thermohaline flow. Long deep water residence times within the eastern Atlantic result in greater remineralization of organic carbon and lower $\delta^{13} \mathrm{C}$ values compared to western Atlantic deep water. Similarly, Pacific deep water shows characteristics which result from mixing of two water masses and excess organic carbon remineralization (Figure 4). The salinity of this deep water shows that it is a mixture of northern and southern component deep water in a ratio of 1 to 3 or 4 , and its $\delta^{13} \mathrm{C}$ composition is about $0.4 \%$ lower than expected if $\delta^{13} \mathrm{C}$ were completely conservative.
The present geographic gradients of $\delta^{13} \mathrm{C}$ in the oceans follow the general distribution of water masses and record the net flow of deep water from the Atlantic to the Pacific. Each of the principal water masses (NADW and AABW) forms in the Atlantic and begins with $\delta^{13} \mathrm{C}$ values that are different from each other, and enriched with respect to the mean ocean $\delta^{13} \mathrm{C}$. During their transit to the Pacific, the isotopic composition of the deep water is altered by the oxidation of organic carbon and mixing, and the net result is a $1.2 \%$ difference in $\delta^{13} \mathrm{C}$ between the deep water present in the northern North Atlantic and the deep water present in the Pacific. Of this observed difference, $0.4 \%$ results from "aging" effects, while $0.8 \%$ results from mixing with southern component deep water. When viewed in transects from the North Atlantic to Antarctic and through to the North Pacific, the principal water masses and the net direction of flow are recorded [Kroopnick, 1985].

In addition to effects of deep water circulation, temporal changes in benthic foraminiferal $\delta^{13} \mathrm{C}$ occur because of global changes in the distribution of carbon between the ocean and various transient reservoirs (e.g., land vegetation, organic carbon in shelf sediments) [Shackleton, 1977b; Broecker, 1982]. Any individual record of benthic foraminiferal $\delta^{13} \mathrm{C}$ can be a complicated combination of global effects, such as changes in the extent of land vegetation or burial of shelf organic carbon, and circulation effects, such as changes in deep water preformed $\delta^{13} \mathrm{C}$ values, residence time within

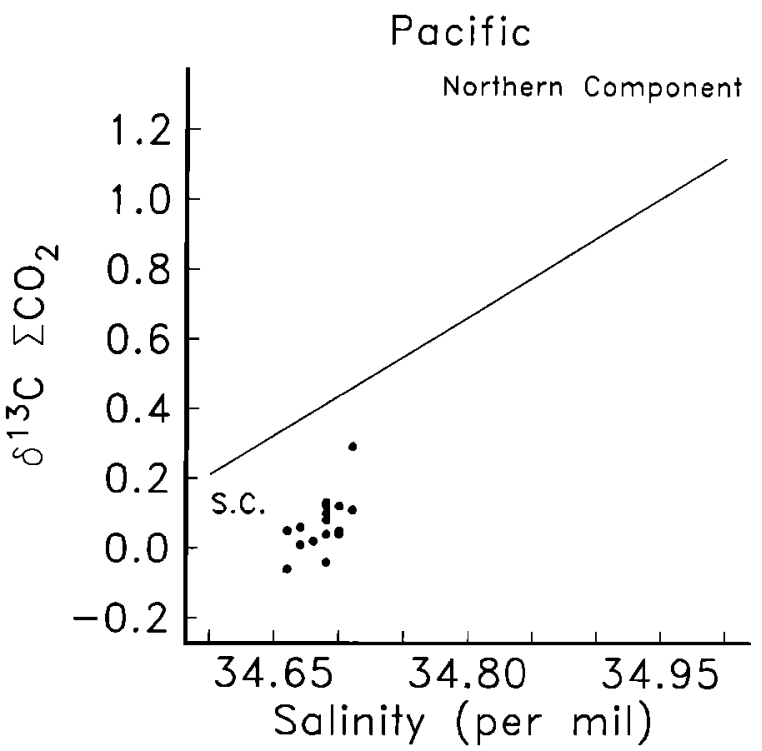

Fig. 4. The relationship between salinity and $\delta^{13} \mathrm{C}$ for the Pacific Ocean from GEOSECS stations $\left(\delta^{13} \mathrm{C}\right.$ data from Kroopnick, [1974]; salinity data from Chung and Craig, [1973]). Note that this deep water mass is a mixture of NADW and AABW, but its $\delta^{13} \mathrm{C}$ composition falls off the mixing line between northern and southern component deep water. The effect of long residence time within the Pacific Ocean allows more degradation of organic carbon within the water mass lowering both its $\delta^{13} \mathrm{C}$ and $\left[\mathrm{O}_{2}\right]$. 
particular basins, or changes in mixing ratios between the principal deep water sources.

But because the ocean mixes thoroughly on time scales of 1000 years or less, all cores in all ocean basins will be affected equally by transfer of carbon between the land and the sea. Consequently, the global effects alter only the mean $\delta^{13} \mathrm{C}$ value for the entire ocean. Synoptic regional gradients in benthic foraminiferal $\delta^{13} \mathrm{C}$ record the important features deep ocean circulation pattern, independent of changes in mean ocean $\delta^{13} \mathrm{C}$. Thus they provide us with the means to reconstruct past patterns or direction of deep water flow and to estimate past changes in deep water residence time or changes in preformed $\delta^{13} \mathrm{C}$ composition. In this paper we will determine the distribution of benthic foraminiferal $\delta^{13} \mathrm{C}$ during the last glacial maximum, evaluate the distribution in terms of changing water mass chemistry, geometry and circulation, and compare the results to modern thermohaline flow.

\section{METHODS}

The analysis of isotopic ratios for oxygen and carbon in foraminiferal tests follows the methods outlined initially by Shackleton and Opdyke [1973]. Foraminiferal tests are cleaned and reacted with $100 \%$ phosphoric acid in a vacuum. The reaction takes place in a constant temperature bath that is usually $50^{\circ} \mathrm{C}$, although the temperature of the reaction is not critical. It is most important that both standards and unknowns are reacted at the same temperature, and this procedure is followed by all of the laboratories reporting data in this paper. The products of the reaction between phosphoric acid and $\mathrm{CaCO}_{3}$ are $\mathrm{CO}_{2}$ and $\mathrm{H}_{2} \mathrm{O}$, and these molecules are separated by fractional distillation using liquid nitrogen and a frozen solvent (e.g., isopropyl alcohol, methanol). The $\mathrm{CO}_{2}$ is then analyzed on a isotopic ratio mass spectrometer. The results are expressed as per mil deviations from PDB, usually through the intermediate calibration standard NBS-20. Analytical precision of standards is reported by most laboratories to be $0.1 \%$ or less. In general, analytical precision is always less than the natural variability observed in replicate analyses of unknown benthic foraminiferal samples.

We present here only isotopic data produced from the analysis of Cibicidoides species and most of the analyses have been produced using $C$. wuellerstorfi. Previous studies [Belanger et al., 1981; Graham et al., 1981; Curry and Lohmann, 1982; Duplessy et al. 1984] have documented the utility and reliability of this species for $\delta^{13} \mathrm{C}$ measurements (Figure 5). Within a given sample, C. wuellerstorf $i$ always has the most enriched $\delta^{13} \mathrm{C}$ composition of the calcitic benthic foraminifera [Woodruff et al., 1980] and is closest to equilibrium with respect to ambient $\delta^{13} \mathrm{C}$ of $\Sigma \mathrm{CO}_{2}$ of the overlying deep water. The $\delta^{13} \mathrm{C}$ composition of $C$. wuellerstorf is lower than the expected isotopic equilibrium values for $\delta^{13} \mathrm{C}$ by about $0.9 \%$ [Rubinson and Clayton, 1969]. Thus it is probably only a coincidence that its observed $\delta^{13} \mathrm{C}$ values are close to ambient $\delta^{13} \mathrm{C}$ of deep water $\mathrm{\Sigma CO}_{2}$. Coexisting $C$. wuellerstorfi and other species of Cibicidoides (e.g., C. kullenbergi, C. bradyı) exhibit no

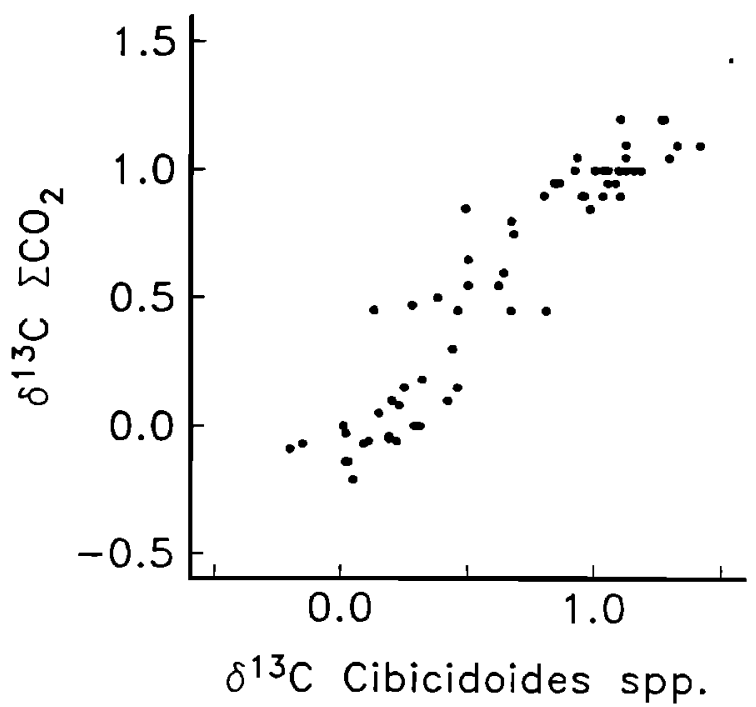

Fig. 5. Measured $\delta^{13} \mathrm{C}$ for ambient sea water $\Sigma \mathrm{CO}_{2}$ and core top Cibicidoides species [after Duplessy et al. 1984]. The isotopic compositions of this benthic taxon reliably reproduce the gradients observed in $\delta^{13} \mathrm{C}$ in the modern ocean. Although the observed $\delta^{13} \mathrm{C}$ values for

Cibicidordes species coincidentally equal ambient $\delta^{13} \mathrm{C}$ of $\Sigma \mathrm{CO}_{2}$, the observed values are lower than expected equilibrium values for calcite by about $0.9 \%$ [Rubinson and Clayton, 1969].

significant differences in $\delta^{13} \mathrm{C}$ [Duplessy et al., 1980; Woodruff et al., 1981; Keigwin, 1982].

We have chosen to analyze Cibucidoides species for three reasons: (1) their $\delta^{13} \mathrm{C}$ variations most reliably reflect the gradients in the modern ocean [Belanger et al., 1981; Graham et al., 1981; Curry and Lohmann, 1982; Duplessy et al., 1984]; (2) the $\delta^{13} \mathrm{C}$ values are closest to carbon isotopic equilibrium; and (3) the limited observations of living, stained individuals demonstrates that Cibicidoides have an epifaunal habitat [Corliss, 1985]. Studies of isotopic variability in core tops show that some species are not reliable recorders of modern ocean gradients in $\delta^{13} \mathrm{C}$ and Apparent Oxygen Utilization (AOU) [Belanger et al., 1981]. We have chosen not to analyze Uvigerina because it does not always produce results which covary with $\delta^{\mathbf{1 3}} \mathrm{C}$ data of Cibicidoides species (compare Graham et al. [1981] with Zahn et al. [1986]). An infaunal habitat has been suggested for Uvigerina [Zahn et al., 1986] and other species [Corliss, 1985], a hypothesis which is consistent with their observed lower $\delta^{13} \mathrm{C}$ compositions, and their temporal variations which parallel changes in sedimentary organic carbon preservation [Zahn et al., 1986]. Although reliable records of $\delta^{13} \mathrm{C}$ change may be produced from other species, in regions where past changes in organic carbon input are suspected the most reliable results will come from analyses of Cibicidoides species.

Restricting analyses to a single species of benthic foraminifera may introduce systematic offsets into our results because glacial-interglacial changes in species 
abundance may create time series that are biased toward one extreme climatic regime. If a species is more abundant in interglacial sediments, then a time series containing only that species may be biased toward interglacial isotopic values because bioturbation will mix more interglacial individuals into glacial samples [Mix and Fairbanks, 1985]. Consequently, no true measurements of glacial maximum conditions will be seen in the time series, underestimating the amplitude of glacial-interglacial $\delta^{13} \mathrm{C}$ changes. This problem can be avoided by carefully recording species abundance (generally expressed as concentration in number/gram sediment) throughout the time series and analyzing only species which have similar concentrations in both glacial and interglacial sediments. Unfortunately, this procedure is not always practical, nor is it always practiced. In general, we try to analyze data from cores with sufficiently high sedimentation rates so that bioturbation problems are minimized. Or we pay careful attention to the oxygen isotopic variations observed in the benthic foraminifera. If the glacial-interglacial amplitude of $\delta^{18} \mathrm{O}$ is reduced by bioturbation [Shackleton, 1977a; Peng et al., 1977], then the carbon isotopic variations may be also affected.

The relationship between sedimentation rate, sampling frequency, and isotopic signal amplitude for our data is
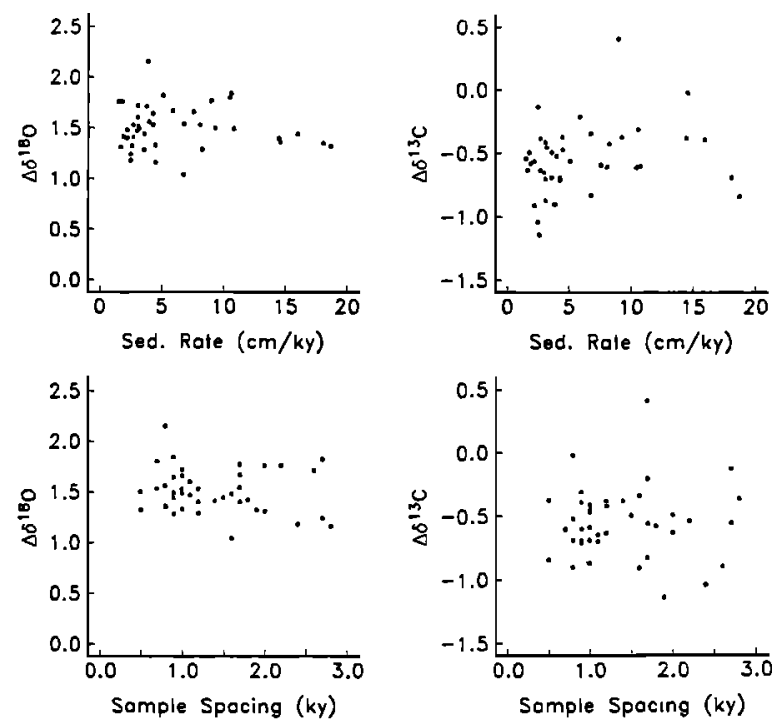

Fig. 6. Glacial-interglacial changes in $\delta^{18} \mathrm{O}$ and $\delta^{13} \mathrm{C}$ as a function of core sedimentation rate and sample spacing. Cores in this data set vary in average sedimentation rate from $1.5 \mathrm{~cm} / \mathrm{kyr}$ to greater than 18 $\mathrm{cm} / \mathrm{kyr}$. Average sample spacing $(\Delta \mathrm{t})$ varies from 0.5 to $2.8 \mathrm{kyr}$ and averages about $1.5 \mathrm{kyr}$. No systematic differences in $\Delta \delta^{18} \mathrm{O}$ can be observed as a function of either sedimentation rate or sample spacing. Thus we believe the data presented here are not biased significantly by bioturbation of low-sedimentation-rate cores or by insufficient sampling frequency. presented in Figure 6. In general, there is no reduction in amplitude in the lower sedimentation rate cores in this data set. At low sedimentation rate $(\sim 2 \mathrm{~cm} / \mathrm{kyr})$ we observe a wide range of glacial-interglacial $\delta^{18} \mathrm{O}$ amplitudes $\left(1.2-1.8 \%\right.$ ), but the observed $\Delta \delta^{18} \mathrm{O}$ at low sedimentation rates are similar to those observed at sedimentation rates greater than $5 \mathrm{~cm} / \mathrm{kyr}$. Thus we believe that there is no reason to delete any cores from this data set based on sedimentation rate alone. Our conclusions support the observations of Pisias [1983], who noted that there was no significant difference between variance spectra of $\delta^{18} \mathrm{O}$ records from cores with sedimentation rates of $2 \mathrm{~cm} / \mathrm{kyr}$ or greater. Within this data set, cores vary in sedimentation from 1.5 to greater than $18 \mathrm{~cm} / \mathrm{kyr}$. Sample spacing $(\Delta \mathrm{t})$ averages approximately $1.5 \mathrm{kyr}$, and we see no effect of sample density on the glacial-interglacial amplitude of $\delta^{18} \mathrm{O}$ (Figure 6). Thus we are confident that the $\delta^{13} \mathrm{C}$ signals that we are reporting are reliable and not significantly affected by bioturbation.

\section{RESULTS}

The isotopic data are tabulated in Appendix 1. We have determined a chronology for each record based on its correlation to Pacific Ocean core V19-30 [Shackleton et al., 1983a, 1983b]. Our correlation of the V19-30 $\delta^{18} \mathrm{O}$ record with the chronology of Imbrie et al. [1984] is presented in Table 2. In the following sections we describe the observed changes in $\delta^{13} \mathrm{C}$ for each ocean basin. A summary of the mean glacial (middle of stage 2, $\sim 17-22 \mathrm{kyr}$ ) and interglacial values (Late IIolocene, $\sim 0-5 \mathrm{kyr})$ of $\delta^{13} \mathrm{C}$ and $\delta^{18} \mathrm{O}$ for each core in this data set are presented Table 3 . We summarize the data for each major ocean basin in Table 4 .

\section{Pacific Ocean}

Typical Pacific records for $\delta^{13} \mathrm{C}$ and $\delta^{18} \mathrm{O}$ are presented in Figure 7. A total of five records are

TABLE 2. Stratigraphic Control Points and Their Estimated Ages in Core V19-30

Depth, m Age, kyr

$\begin{array}{rr}0.00 & 0.0 \\ 0.93 & 12.0 \\ 1.16 & 15.0 \\ 2.60 & 24.0 \\ 4.70 & 59.0\end{array}$

The ages of the control points are from Imbrie et al. [1984], except for the control point at $1.16 \mathrm{~m}$, which is from Shackleton and Pisias [1985]. 
tabulated in Appendix 1, and their mean glacial-interglacial difference equals $1.49 \%$ for $\delta^{18} \mathrm{O}$ and $-0.41 \%$ for $\delta^{13} \mathrm{C}$ (Table 4). The variability in isotopic composition appears to increase during the glacial maximum, as noted by the larger standard deviations for mean glacial $\delta^{18} \mathrm{O}$ and $\delta^{13} \mathrm{C}$ values. Unfortunately, because of the small number of cores from the Pacific Ocean the difference is not highly significant. Today the Pacific is remarkably homogenous in its $\delta^{13} \mathrm{C}$ composition [Kroopnick, 1974, 1985], and this homogeneity is reflected by the low variability in $\delta^{13} \mathrm{C}$ observed in the average Late Holocene $\delta^{13} \mathrm{C}$ values (Table 4). Similarly, temperature and salinity $\left(\delta^{18} \mathrm{O}_{w}\right)$ variations in the deep Pacific are small, so the variability observed in $\delta^{18} \mathrm{O}$ of Cibicidoides in the Late Holocene Pacific samples is also low. The increased variability observed in the glacial Pacific data may suggest that the Pacific was more heterogenous in its $\delta^{13} \mathrm{C}$ distribution.

\section{Southern Ocean}

Figure 8 presents two isotopic records from representative cores of the southern ocean. RC13-229 [Oppo and Fairbanks, 1987] and MD84-527 [Labeyrie et al., 1986] demonstrate that the glacial-interglacial change

TABLE 3. Mean Values of $\delta^{13} \mathrm{C}$ for Late Holocene (0-5 kyr) and Glacial (17-22 kyr) for Each Core Listed in Appendix 1

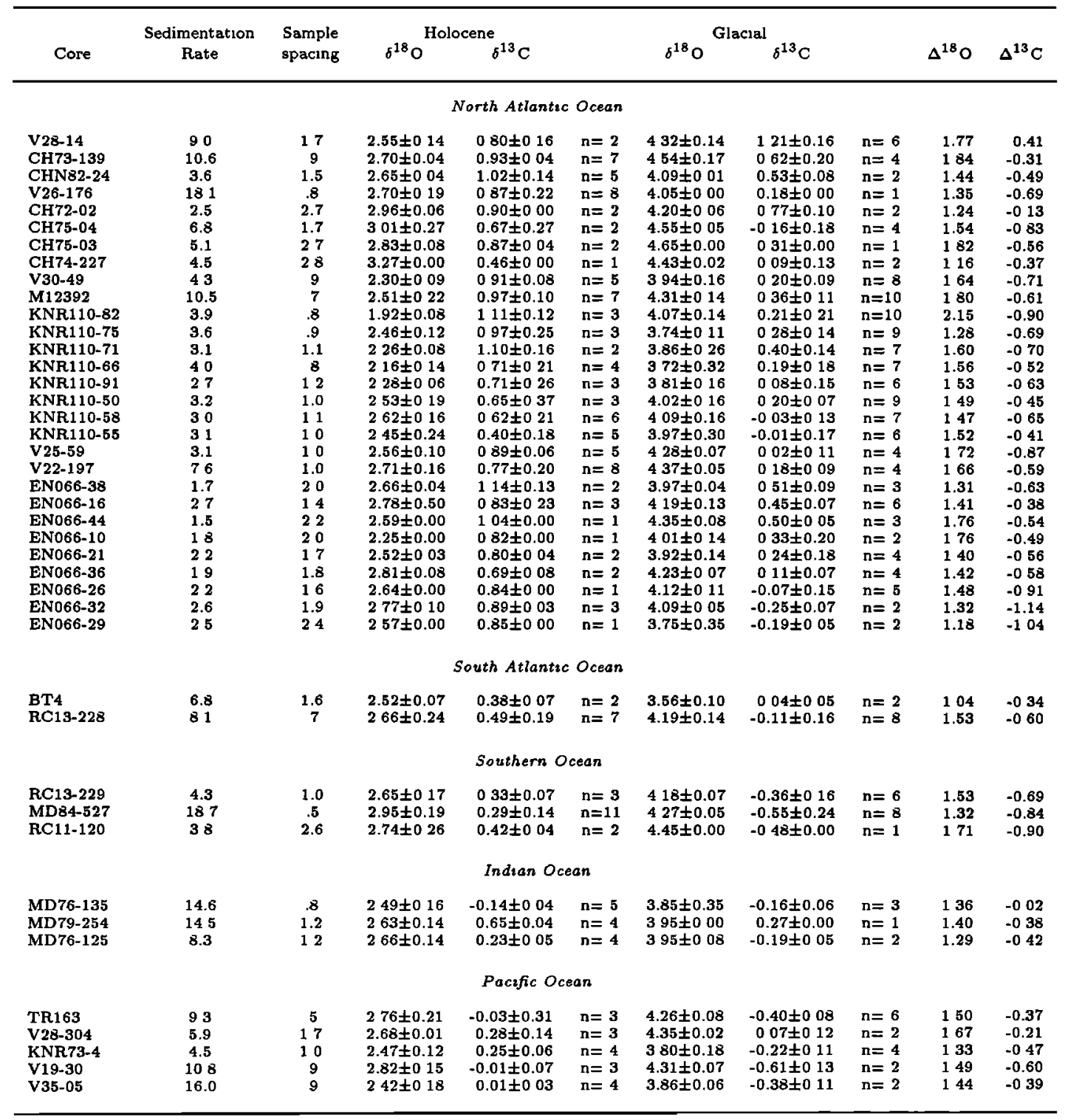

The mean isotopic values were determined as averages of all data which fell within the prescribed stratigraphic intervals. The data are presented with respect to PDB, with no corrections for disequilibrium fractionation. All data are from Cibicidoides species. $\Delta$ equals the isotopic difference between glacial $(17-22 \mathrm{kyr})$ and interglacıal (0-5 kyr) means for each core expressed as (glacial - interglacial). 
TABLE 4. Mean Values of $\delta^{18} \mathrm{O}$ and $\delta^{13} \mathrm{C}$ for Late Holocene (0-5 kyr) and Glacial (17-22 kyr) Summarized for Each Ocean Basin

\begin{tabular}{lccccc}
\hline & \multicolumn{2}{c}{ Late Holocene } & & \multicolumn{2}{c}{ Glacial } \\
\cline { 2 - 3 } \cline { 5 - 6 } Ocean & $\delta^{18} \mathrm{O}$ & $\delta^{13} \mathrm{C}$ & & $\delta^{18} \mathrm{O}$ & $\delta^{13} \mathrm{C}$ \\
\hline North Atlantic, $\mathrm{n}=29$ & $2.59 \pm 0.27$ & $0.84 \pm 0.18$ & $4.13 \pm 0.25$ & $0.25 \pm 0.31$ \\
South Atlantic, $\mathrm{n}=2$ & $2.59 \pm 0.10$ & $0.44 \pm 0.08$ & $3.88 \pm 0.45$ & $-0.04 \pm 0.11$ \\
Indian, $\mathrm{n}=3$ & $2.59 \pm 0.09$ & $0.25 \pm 0.40$ & $3.92 \pm 0.06$ & $-0.03 \pm 0.26$ \\
Southern, $\mathrm{n}=3$ & $2.78 \pm 0.15$ & $0.35 \pm 0.07$ & $4.30 \pm 0.14$ & $-0.46 \pm 0.10$ \\
Pacific, $\mathrm{n}=5$ & $2.63 \pm 0.18$ & $0.10 \pm 0.15$ & $4.12 \pm 0.26$ & $-0.31 \pm 0.25$ \\
\hline
\end{tabular}

in $\delta^{13} \mathrm{C}$ of the southern ocean is the largest observed in any ocean. Mean glacial-interglacial differences in $\delta^{13} \mathrm{C}$ are $-0.81 \%$, while the $\delta^{18} \mathrm{O}$ difference equals $1.52 \%$. Most significantly, the southern ocean cores have the lowest $\delta^{13} \mathrm{C}$ values observed in the glacial ocean (Table 4). The average values for all other ocean basins are at least $0.15 \%$ enriched in ${ }^{13} \mathrm{C}$ with respect to the southern ocean values. Geographic variability in $\delta^{13} \mathrm{C}$ and $\delta^{18} \mathrm{O}$ is low during both the interglacial and glacial, as shown by standard deviations of about $0.1 \% 0$ or less for both $\delta^{13} \mathrm{C}$ and $\delta^{18} \mathrm{O}$ (Table 4).

\section{Indian Ocean}

The isotopic records from three cores in the Indian ocean are presented in Figure 9. MD76-125 and MD79-254 each exhibit glacial-interglacial changes in $\delta^{13} \mathrm{C}$ which are near to mean ocean changes $(-0.4 \%)$. The third core (MD76-135) shows no change in its $\delta^{13} \mathrm{C}$. MD76-135 and MD76-125 were recovered from the same water depth $(\sim 1800 \mathrm{~m})$, so the differences in $\delta^{13} \mathrm{C}$ are not simply related to depth differences in the water column. These Indian Ocean cores average $1.33 \%$

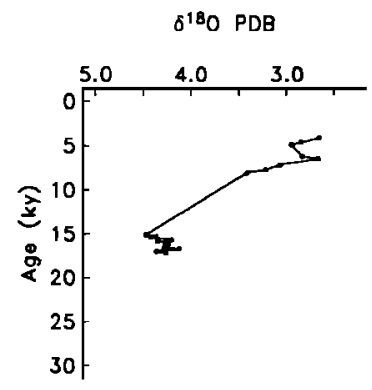

$\delta^{13} \mathrm{C}$ PDB

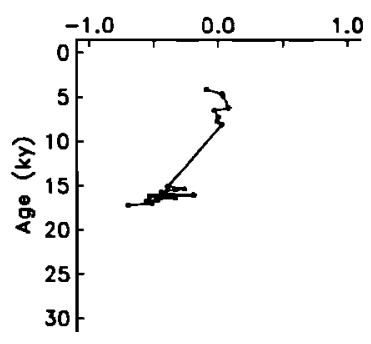

V19-30

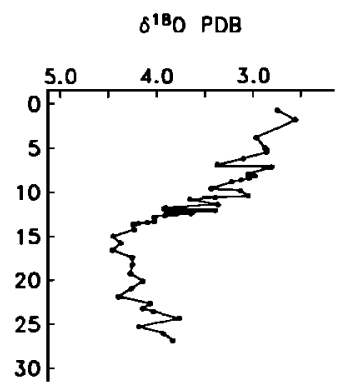

$\delta^{13} \mathrm{C}$ PDB

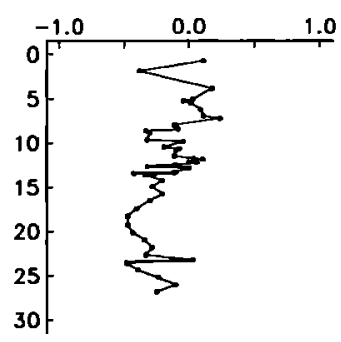

TR163-31
$8^{18} \mathrm{OPDB}$

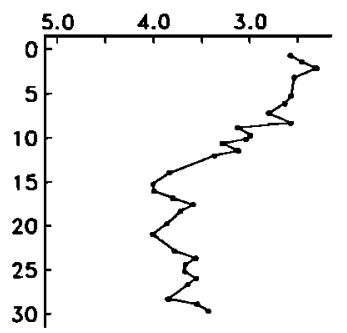

$\delta^{13} \mathrm{CPDB}$

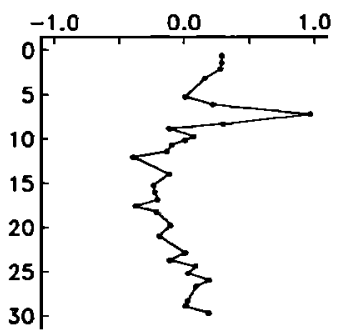

KNR73-4-3

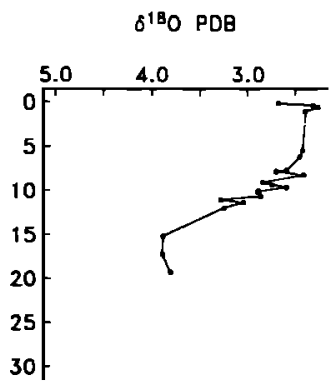

$\delta^{13} \mathrm{CPDB}$

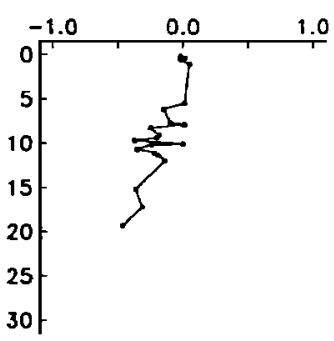

v35-05

Fig. 7. Isotopic records for Pacific Ocean cores demonstrate the changes in $\delta^{13} \mathrm{C}$ which are typical of this basin. Interglacial-glacial changes in $\delta^{18} \mathrm{O}$ and $\delta^{13} \mathrm{C}$ for the Pacific Ocean as a whole equal $1.49 \% 0$ and $-0.41 \%$ respectively (Table 4 ). 

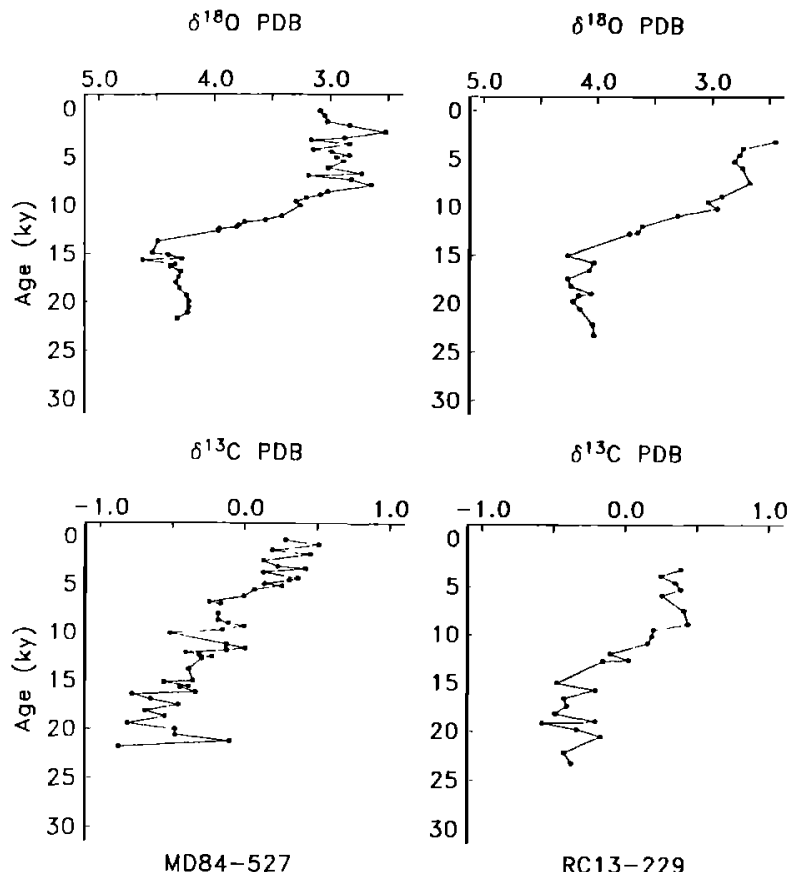

Fig. 8. Isotopic records for two southern ocean cores showing the changes in $\delta^{13} \mathrm{C}$ which are typical of this basin. Interglacial-glacial changes in $\delta^{18} \mathrm{O}$ and $\delta^{13} \mathrm{C}$ for this ocean equal $1.52 \%$ and $-0.81 \%$, respectively (Table 4).

enriched in $\delta^{18} \mathrm{O}$ during the glacial maximum and $0.28 \%$ depleted in ${ }^{13} \mathrm{C}$ (Table 4). All of the cores are located near to margins of the Indian Ocean and may not be representative of the isotopic changes observed in pelagic regions of this ocean basin.

\section{Atlantic Ocean}

The Atlantic Ocean has been the focus of extensive research on deep water circulation studies because of its abundant carbonate sediments, simple stratigraphic tools, and large number of high-quality cores. Consequently, we have compiled a collection of 31 isotopic records for this ocean basin for the last glacial-interglacial transition. Of these cores, two are located in the South Atlantic, and they averaged 1.29\% greater in $\delta^{18} \mathrm{O}$ and $0.48 \%$ less in $\delta^{13} \mathrm{C}$ during the glacial maximum (Table 4). Twenty-nine North Atlantic cores averaged $1.54 \%$ greater in $\delta^{18} \mathrm{O}$ and $0.59 \%$ less in $\delta^{13} \mathrm{C}$ during the glacial maximum. Like the Pacific Ocean, the glacial maximum $\delta^{13} \mathrm{C}$ samples in the North Atlantic have nearly twice the standard deviation of the Late Holocene samples, suggesting that greater heterogeneity occurred in the geographic distribution of $\delta^{13} \mathrm{C}$ during the glaciation than today. This difference in standard deviation is significant with a high degree of confidence $(p<0.1)$.

The glacial-interglacial amplitude of $\delta^{13} \mathrm{C}$ varies regionally and with depth in the Atlantic Ocean (Figure $10)$. Cores from shallow depths $(<2000 \mathrm{~m})$ in the Atlantic appear to be enriched in ${ }^{13} \mathrm{C}$ during the glacial maximum [Boyle and Keigwin, 1986; Zahn and Sarnthein, 1986; Cofer-Shabica and Peterson, 1986; Oppo and Fairbanks, 1987]. V28-14, in the Norwegian-Greenland Sea at $1855 \mathrm{~m}$, shows a $\delta^{13} \mathrm{C}$ enrichment of $0.4 \%$ during the glacial maximum (Table 3). At depths below $2000 \mathrm{~m}$ in the Atlantic, $\delta^{13} \mathrm{C}$ is always lower during the glacial maximum than during the Late Holocene. In the northern North Atlantic the amplitude is about 0.3-0.5\% $\%$. The amplitude increases toward the south (Figure 10), and near the present mixing zone between northern and southern water masses at the equator, cores which are presently located in NADW display glacial-interglacial amplitudes of $0.5-0.9 \%$ in $\delta^{13} \mathrm{C}$. The largest variations in $\delta^{13} \mathrm{C}$ occur in the deep eastern Atlantic (below $4700 \mathrm{~m}$ ), where glacial-interglacial differences in $\delta^{13} \mathrm{C}$ exceed $1.0 \%$ (Table 3).

\section{DISCUSSION}

\section{Global Deep Water $\delta^{13} C$ Change}

Based on the information in Table 4, we have determined the mean change in $\delta^{13} \mathrm{C}$ and $\delta^{18} \mathrm{O}$ of the deep ocean. We averaged all of the cores analyzed within each ocean basin (Pacific, Indian, and Atlantic) and determined a mean change in benthic foraminiferal isotopic composition for the whole ocean weighted by the volumetric fraction of each ocean. The results are presented in Table 5 . On average, the $\delta^{13} \mathrm{C}$ composition of the deep water was $0.46 \%$ lower during the last glacial maximum than during the Late Holocene. This mean value equals the value presented by Boyle and

TABLE 5. Mean Glacial-Interglacial Changes in $\delta^{18} \mathrm{O}$ and $\delta^{13} \mathrm{C}$ and Volumetric Fraction of Each Ocean Used to Calculate the Mean Change in Deep Water Isotopic Composition

\begin{tabular}{lccc}
\hline Ocean & $\begin{array}{c}\text { Volume } \\
\times 10^{6} \mathrm{~km}^{3}\end{array}$ & $\delta^{18} \mathrm{O}$ & $\delta^{13} \mathrm{C}$ \\
\hline Pacific & 656 & 1.49 & -0.41 \\
Atlantic & 295 & 1.52 & -0.58 \\
Indian & 246 & 1.33 & -0.28 \\
Southern & 123 & 1.52 & -0.81 \\
Mean Ocean & 1320 & 1.47 & -0.46 \\
\hline
\end{tabular}

The isotopic data are from Table 4, and the occan volumes are from Worthington [1981]. The southern ocean volume includes Pacific, Indian and Atlantic Ocean sectors. 


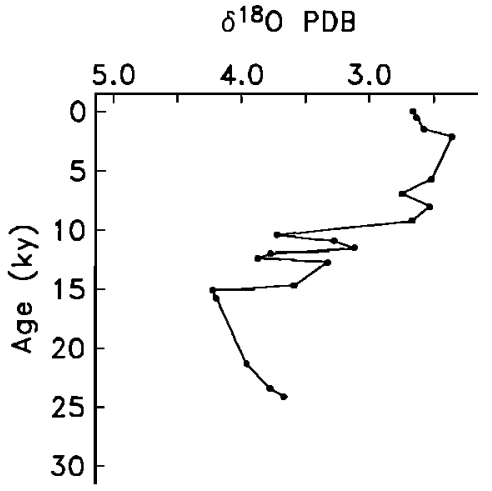

$\delta^{13} \mathrm{C}$ PDB

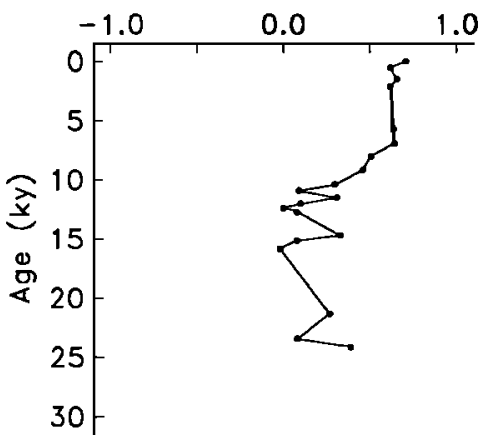

MD79-254

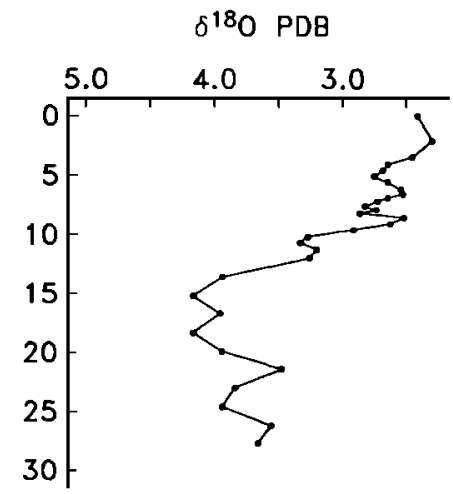

$\delta^{13} \mathrm{C}$ PDB

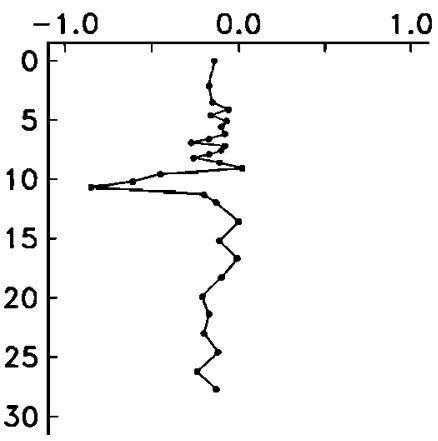

MD76- 135 $\delta^{18} \mathrm{O} P D B$

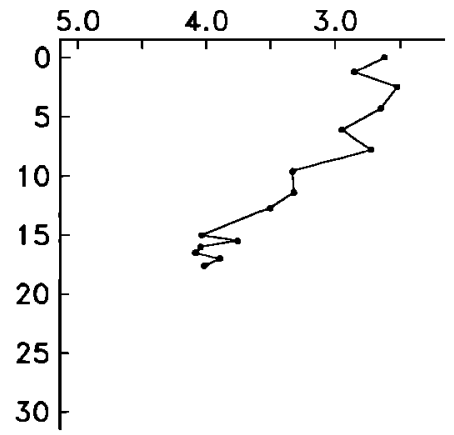

$\delta^{13} \mathrm{C}$ PDB

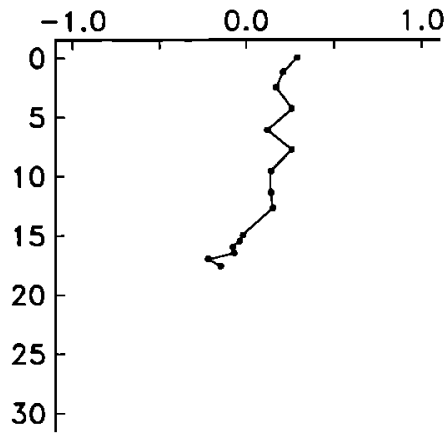

MD76- 125

Fig. 9. Isotopic records for three cores from the Indian Ocean. Interglacial-glacial differences in $\delta^{18} \mathrm{O}$ and $\delta^{13} \mathrm{C}$ average $1.33 \%$ and $-0.28 \%$, respectively, in the Indian Ocean. These cores are from marginal locations in the Indian Ocean; consequently, the average isotopic changes may not be representative of pelagic regions of the Indian Ocean.

Keigwin $[1985 / 86]$, which they calculated using one core each from the Atlantic and Pacific oceans. The data presented in this paper show that their cores were representative of the mean changes of the deep water in those ocean basins as a whole. The data from the southern and Indian oceans, added to the global data set in this paper, have a mean glacial-interglacial difference which is near to the value presented by Boyle and Keigwin $[1985 / 86]$. This mean value $(0.46 \%)$ probably will not change significantly from the addition of new deep water $\delta^{13} \mathrm{C}$ records because it is now based on a large data set from the Atlantic Ocean and an adequate data set from the Pacific Ocean. Only the addition of more cores from the Indian Ocean is likely to affect our estimate of the mean glacial-interglacial $\delta^{13} \mathrm{C}$ change for deep water. Because the cores in our data set are dominantly from below $2000 \mathrm{~m}$ water depth, our average reflects only the mean changes in deep water $\delta^{13} \mathrm{C}$. Our estimate is larger than the $0.32 \%$ decrease calculated by Duplessy et al. [this issue], because these authors attempted to quantify the $\delta^{13} \mathrm{C}$ changes in intermediate water masses during the last glaciation. To the extent that shallow cores appear to have increased in $\delta^{13} \mathrm{C}$ during the last glacial maximum, our value is a maximum estimate of the global $\delta^{13} \mathrm{C}$ change.

\section{Atlantic Ocean Glacıal Circulation}

The principal changes in circulation of the Atlantic Ocean include: (1) decreased production of nutrient-depleted deep water $(>2000 \mathrm{~m})$ in the North Atlantic, (2) greater northward penetration of $10{ }^{13}{ }^{13} \mathrm{C}$ deep water from southern ocean source regions, and (3) the presence of a nutrient-depleted intermediate water mass shallower than $2000 \mathrm{~m}$. These results are based on the observed changes in the geographic distribution of $\delta^{13} \mathrm{C}$ during the glaciation. During the last glacial maximum, southern ocean deep water became reduced in $\delta^{13} \mathrm{C}$ by more than $0.8 \%$ (Table 4 ). Cores presently within NADW decreased in $\delta^{\mathbf{1 3}} \mathrm{C}$ by about $0.5 \%$ during the glaciation in the North Atlantic, but toward the equatorial region, the amplitude of $\delta^{13} \mathrm{C}$ increased (Figure 10). At this time, the isotopic composition of western equatorial cores fell between northern North Atlantic and southern ocean values (Figure 11). Because mixing between water masses of different composition is the principal method for altering the distribution of $\delta^{13} \mathrm{C}$ in the western basins of the Atlantic (see Figure 2), these results suggest that the mixing zone between northern and southern component deep water migrated to the north during the glacial maximum. Our observations 


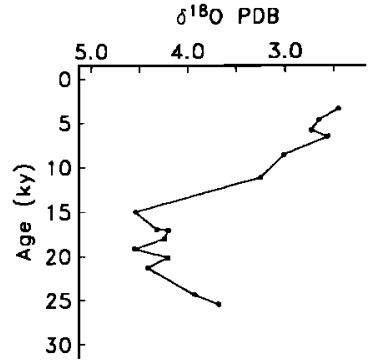

$\delta^{13} \mathrm{CPDB}$

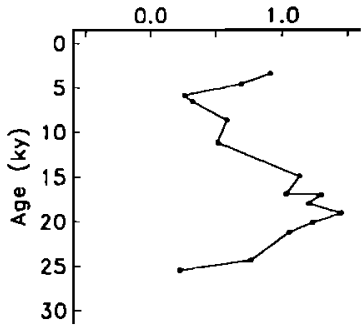

V28-14

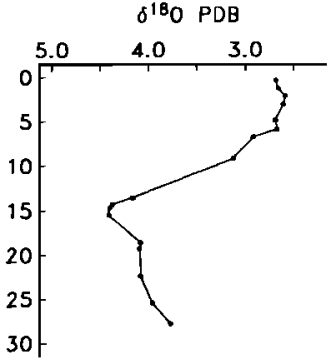

$\delta^{13} \mathrm{C}$ PDB

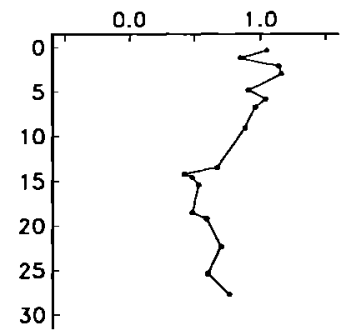

CHN82-24

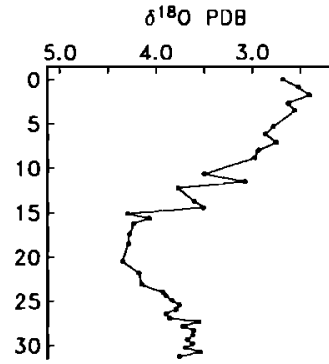

$\delta^{13} \mathrm{C}$ PDB

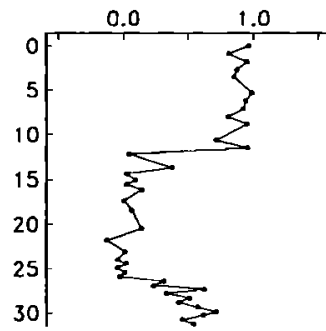

V25-59
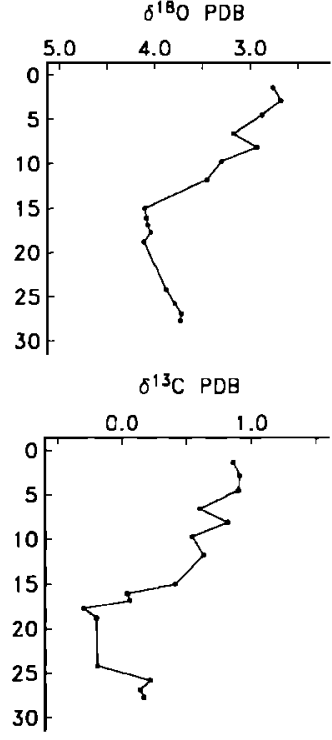

EN066-32

Fig. 10. Isotopic records for Atlantic Ocean cores. V28-14 is from the Norwegian-Greenland Sea at about $1800 \mathrm{~m}$ water depth. It is the only core in this data set which increases in $\delta^{\mathbf{1 3}} \mathrm{C}$ during the glacial maximum. All cores from below $2000 \mathrm{~m}$ decrease in $\delta^{13} \mathrm{C}$ during the glaciation, and their amplitude increases toward the equator (V25-59). Highest amplitude $\delta^{13} \mathrm{C}$ records and lowest glacial values are observed in the deep eastern Atlantic below $4700 \mathrm{~m}$.

support the observations and conclusions of Oppo and Fairbanks [1987].

The lowest $\delta^{13} \mathrm{C}$ values observed in the glacial Atlantic Ocean are found in eastern Atlantic locations below 4700 m. Curry and Lohmann [1983, 1985] suggested that these values resulted from the increased residence time of the deep water, resulting from decreased glacial production of NADW. They assumed that the input composition of the deep water entering the eastern Atlantic through low-latitude fracture zones had a $\delta^{13} \mathrm{C}$ value equal to the $\delta^{13} \mathrm{C}$ values of cores in the eastern equatorial Atlantic from above the sill depth of the fracture zones. Thus they assumed that the bathymetric gradient in $\delta^{13} \mathrm{C}$ of $0.7 \%$ approximated the geographic difference in $\delta^{13} \mathrm{C}$ between the western and eastern basins of the equatorial Atlantic. It is clear from the above discussion that a greater proportion of southern component deep water was flowing into the western Atlantic during the glaciation [Oppo and Fairbanks, 1987] and that this affected the input composition of the deep water flowing into the eastern Atlantic Ocean. The $\delta^{13} \mathrm{C}$ value of this ventilating deep water (at the sill depth of the Romanche Fracture Zone, $\sim 4000 \mathrm{~m}$ ) is best recorded by the western Atlantic $\delta^{13} \mathrm{C}$ records of KNR110-50 and KNR110-58, which have average glacial $\delta^{13} \mathrm{C}$ values of 0.20 and $-0.03 \%$, respectively (Table 3 ). The lowest $\delta^{13} \mathrm{C}$ values observed in the deepest eastern equatorial Atlantic are -0.19 and $-0.25 \%$, respectively, for EN066-29 and and EN066-32. Since lower values are observed in the eastern Atlantic than are observed at any depth in the western Atlantic, some alteration of the isotopic value of the deep water must have occurred after it enter the eastern basin (see Figure 3). However, this effect of the longer residence time on the glacial isotopic records of the deep eastern Atlantic cores is limited to a maximum of $0.1-0.3 \% \delta^{13} \mathrm{C}$ out of the total bathymetric decrease of $0.7 \%$ observed in the eastern basin. This $0.1-0.3 \%$ difference in $\delta^{13} \mathrm{C}$ because of increased carbon remineralization is similar to the magnitude of this effect today (compare Figure 2 with Figure 3 ).

The presence of a ${ }^{13} \mathrm{C}$ enriched water mass shallower than $2000 \mathrm{~m}$ is observed in the limited data presented in this paper. Convincing evidence for the geographic extent of this intermediate water mass has been presented by Zahn and Sarnthein [1986], who mapped the bathymetric distribution of enriched ${ }^{13} \mathrm{C}$ values in glacial benthic foraminifera sampled on the west African continental margin, and by Cofer-Shabica and Peterson [1986], Boyle and Keigwin [1986], and Oppo and Fairbanks [1987], who determined that glacial Caribbean benthic foraminifera were enriched in ${ }^{13} \mathrm{C}$ and depleted in Cd. Because the Caribbean is ventilated through straits with a sill depth of about $1800 \mathrm{~m}$, the dominant signal measured in this marginal sea reflects changes in $\delta^{13} \mathrm{C}$ at 1800 meters in the North Atlantic. The source of this intermediate water is not yet confirmed, but Zahn and Sarnthein [1986] and Oppo and Fairbanks [1987] suggest that the Mediterranean Sea is the likely source. Oppo and Fairbanks [1987] demonstrate that glacial

Mediterranean outflow was probably higher in $\delta^{13} \mathrm{C}$ than Holocene outflow.

\section{Glacial Pacific Deep Water}

Two aspects of the $\delta^{13} \mathrm{C}$ data for the Pacific suggest that there may have been source of nutrient-depleted 


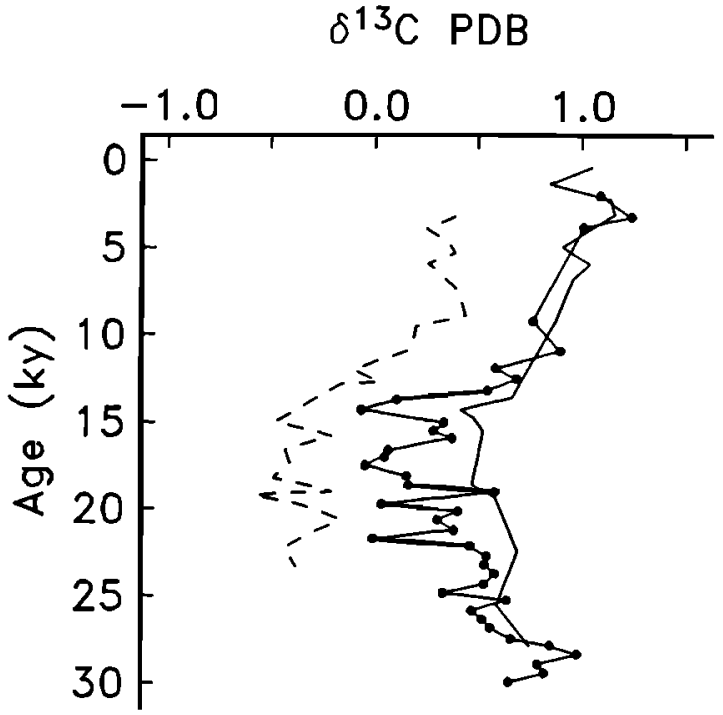

Fig. 11. Carbon isotopic variations in KNR110-82 from the western equatorial Atlantic Ocean. Lines indicate the $\delta^{13} \mathrm{C}$ changes in one core from the North Atlantic (Solid line: CHN82-24) and one core from the southern ocean (Dashed line: RC13-229). Note that the equatorial Atlantic core and the North Atlantic core have equal $\delta^{13} \mathrm{C}$ values during the Late Holocene. During the glaciation, the equatorial Atlantic core has values which are between southern ocean and North Atlantic values. Since mixing is the dominant process affecting the $\delta^{13} \mathrm{C}$ distribution within the western basins of the Atlantic today, these results demonstrate that the mixing zone between northern and southern component deep water migrated to the north during the glacial maximum.

water produced in this ocean. The mean value of benthic foraminiferal $\delta^{13} \mathrm{C}$ in the Pacific Ocean is greater than the mean value of $\delta^{13} \mathrm{C}$ for the southern ocean during the glacial maximum (Table 4). Today, the $\delta^{13} \mathrm{C}$ composition of southern ocean deep water falls between the values of NADW and mean Pacific Ocean deep water because it is a mixture of these two components. Thus Late Holocene benthic foraminifera from the southern ocean are higher in $\delta^{13} \mathrm{C}$ than Pacific bentlic foraminifera (Table 4). During the last glacial maximum, the mean isotopic composition of southern ocean benthic foraminifera was $0.15 \%$ lower than Pacific Ocean benthic foraminifera. Although the small number of records in each ocean basin limits our confidence in this difference, it has important implications about Pacific Ocean deep circulation. Since both NADW and Pacific deep water were enriched in ${ }^{13} \mathrm{C}$ compared to southern ocean deep water, southern ocean deep water could not have been a simple mixture of NADW and recirculated Pacific deep water as it is today. Oppo and Fairbanks [1987] first noted that Pacific and Southern Ocean benthic foraminifera were similar in $\delta^{\mathbf{1 3}} \mathrm{C}$ during the glaciation and concluded that glacial northern Atlantic water was not mixed into this region. Our results extend this observation to suggest that a separate source of nutrient-depleted water may have mixed with southern ocean water to produce the Pacific $\delta^{13} \mathrm{C}$ values.

Close examination of the Pacific data shows that some individual cores have glacial $\delta^{13} \mathrm{C}$ values as low as southern ocean cores, while others are greatly enriched in ${ }^{13} \mathrm{C}$ (Table 3). Heterogeneity like this normally would support an hypothesis of mixing between two water masses in the glacial Pacific Ocean. In the modern Pacific Ocean the geographic variability of $\delta^{13} \mathrm{C}$ is small and results in the low standard deviation for the mean value presented in Table 4 . In contrast, the mean value for the glacial samples shows a larger standard deviation suggesting that there was greater geographic variability in $\delta^{13} \mathrm{C}$ at that time. Greater variability within the Pacific basin may have resulted from production of deep water within the Pacific and mixing between this water mass and southern ocean deep water. This mixing would produce a standard deviation of the $\delta^{13} \mathrm{C}$ values which approaches the standard deviation observed in the present-day and glacial Atlantic Oceans, where mixing between two water masses is clearly an active process. But two ambiguities limit our conclusions about mixing between Pacific water masses: (1) Because of the small number of samples in our Pacific data set the difference in variance is not significant with a high degree of statistical confidence. Only a more extensive suite of Pacific $\delta^{13} \mathrm{C}$ records will confirm our observations. (2) The two Pacific cores with the most enriched glacial $\delta^{13} \mathrm{C}$ values (V28-304 and KNR73-3) are not located near to each other, so we cannot develop a simple geometry for mixing between water masses of different composition.

\section{CONCLUSIONS}

1. The geographic distribution of $\delta^{13} \mathrm{C}$ is controlled by photosynthetic removal of carbon from the surface ocean and oxidative degradation in the deep ocean. Water masses are formed at the surface by cooling and mixing of water types with different preformed $\delta^{13} \mathrm{C}$ values. After removal from the surface ocean, $\delta^{13} \mathrm{C}$ of a water mass changes only as a result of mixing between two water masses, or from the oxidation of the organic particles settling through the water column. The relative intensities of these two effects vary regionally because of the dynamics of deep water circulation and differences in surface water productivity within and between oceans. Today, the $\delta^{13} \mathrm{C}$ distribution in the western Atlantic is dominated by mixing between NADW and southern-source deep water because of the presence of these two water masses flowing in opposite directions within that basin and because surface water productivity is very low in the Atlantic Ocean. In contrast, the $\delta^{13} \mathrm{C}$ values of the eastern Atlantic and the Pacific oceans are each lower than would be expected if mixing alone controlled their distribution. Degradation of organic carbon because of longer residence times within these basins (the "aging" effect) has lowered the $\delta^{13} \mathrm{C}$ values by $0.2 \%$ in the eastern Atlantic and up to $0.4 \%$ in the Pacific.

2. $\delta^{13} \mathrm{C}$ values of the genus Cibicidoides faithfully record the gradients in isotopic composition of the overlying bottom water. Thus the chemistry of their 
shells provides us with a unique record of the past distribution of $\delta^{13} \mathrm{C}$ in the oceans. Since the geographic distribution of $\delta^{13} \mathrm{C}$ is controlled to a great extent by circulation patterns, we can evaluate the changes in $\delta^{13} \mathrm{C}$ in terms of changes in botlom and deep water circulation and chemistry.

3. Largest glacial-interglacial changes in $\delta^{13} \mathrm{C}$ occur in southern ocean cores $(0.8 \%$ ), followed by Atlantic $(0.5 \%)$ and Pacific $(0.3 \%)$ cores. In the modern ocean, lowest observed $\delta^{13} \mathrm{C}$ values occur in the Pacific Ocean, where the effects of long residence time have lowered the $\delta^{13} \mathrm{C}$ value by $0.4 \%$ from its conservative-mixing value. Late Holocene $\delta^{13} \mathrm{C}$ values for southern ocean fall between the values of NADW and recirculated Pacific deep water, showing the effects of mixing ${ }^{13} \mathrm{C}$-enriched NADW into the southern ocean. During the glaciation, southern ocean cores have lowest observed $\delta^{13} \mathrm{C}$ values, demonstrating that reduced glacial production of NADW decreased its effect on southern ocean chemistry. Since Pacific Ocean cores also have greater $\delta^{13} \mathrm{C}$ values than southern ocean cores during the last glacial maximum, some alternate source of nutrient-depleted water must have been produced in the Pacific Ocean.

4. High-amplitude changes in $\delta^{13} \mathrm{C}$ in equatorial Atlantic cores probably resulted from increased northward penetration of a low- $\delta^{13} \mathrm{C}$ southern-source deep water into the North Atlantic during the glaciation. The lowest $\delta^{13} \mathrm{C}$ values in the equatorial region occur in the deep eastern Atlantic, and these values are near in composition to southern ocean $\delta^{13} \mathrm{C}$ values. Western equatorial Atlantic locations also have low values during the glaciation, but the values are about $0.2 \%$ higher than in the deep eastern Atlantic. This difference places a maximum constraint on the effects of increased residence time on eastern Atlantic $\delta^{13} \mathrm{C}$ values, and it is similar in magnitude to the effect of residence time observed in the modern eastern Atlantic.

\section{APPENDIX 1. ISOTOPIC DATA FOR Cibicidoides spp. FROM CORES DISTRIBUTED TIIROUGHOUT THE WORLD'S OCEAN}

\begin{tabular}{|c|c|c|c|c|c|c|c|c|c|c|c|}
\hline Depth, m & Age, kyr & $\delta^{18} \mathrm{O}$ & $\delta^{13} \mathrm{C}$ & Depth, m & Age, kyr & $\delta^{18} \mathrm{O}$ & $\delta^{13} \mathrm{C}$ & Depth, m & Age, kyr & $\delta^{18} \mathrm{O}$ & $\delta^{13} \mathrm{C}$ \\
\hline \multirow{4}{*}{\multicolumn{2}{|c|}{$\begin{array}{l}\text { Core: V28-14 } \\
65^{\circ} \mathrm{N} 30^{\circ} \mathrm{W} \\
1855 \mathrm{~m}\end{array}$}} & & & \multicolumn{4}{|c|}{ Core: CH73-139C } & 1.600 & 13.7 & 4.42 & 0.59 \\
\hline & & & & \multicolumn{4}{|c|}{$55^{\circ} \mathrm{N} 16^{\circ} \mathrm{W}$} & 1.700 & 15.1 & 4.81 & 0.61 \\
\hline & & & & \multicolumn{4}{|l|}{$2209 \mathrm{~m}$} & 1.750 & 15.6 & 4.59 & 0.71 \\
\hline & & & & & & & & 1.850 & 16.7 & 4.54 & 0.72 \\
\hline 0.500 & 3.5 & 2.45 & 0.91 & 0.000 & 0.0 & 2.67 & 0.96 & 1.900 & 17.3 & 4.61 & 0.74 \\
\hline 0.700 & 4.7 & 2.65 & 0.69 & 0.150 & 1.2 & 2.66 & 0.95 & 2.000 & 18.3 & 4.56 & 0.80 \\
\hline 0.900 & 5.9 & 2.64 & 0.28 & 0.200 & 1.6 & 2.65 & 0.93 & 2.100 & 19.4 & 4.30 & 0.56 \\
\hline 0.900 & 5.9 & 2.82 & 0.25 & 0.300 & 2.4 & 2.68 & 0.89 & 2.250 & 21.0 & 4.70 & 0.36 \\
\hline 1.000 & 6.6 & 2.56 & 0.32 & 0.400 & 3.2 & 2.72 & 0.96 & 2.350 & 22.1 & 4.69 & 0.36 \\
\hline 1.100 & 8.7 & 3.02 & 0.58 & 0.500 & 4.0 & 2.75 & 0.88 & 2.450 & 23.2 & 4.58 & 0.61 \\
\hline 1.200 & 11.2 & 3.25 & 0.51 & 0.600 & 4.8 & 2.74 & 0.97 & 2.550 & 24.2 & 4.22 & 0.43 \\
\hline 1.300 & 15.0 & 4.54 & 1.13 & 0.700 & 5.6 & 2.83 & 0.76 & 2.650 & 25.3 & 4.18 & 0.51 \\
\hline 1.490 & 17.0 & 4.32 & 1.03 & 0.850 & 6.8 & 2.90 & 0.69 & 2.750 & 26.4 & 4.30 & 0.65 \\
\hline 1.500 & 17.1 & 4.20 & 1.30 & 0.900 & 7.2 & 2.91 & 0.76 & 2.850 & 27.5 & 4.57 & 0.54 \\
\hline 1.600 & 18.1 & 4.42 & 1.07 & 1.000 & 8.0 & 2.97 & 0.67 & 3.000 & 29.1 & 4.76 & 0.26 \\
\hline 1.600 & 18.1 & 4.06 & 1.32 & 1.100 & 8.8 & 3.01 & 0.73 & 3.100 & 30.1 & 4.47 & 0.25 \\
\hline 1.700 & 19.2 & 4.55 & 1.45 & 1.200 & 9.6 & 3.48 & 0.89 & 3.200 & 31.2 & 4.49 & 0.06 \\
\hline 1.800 & 20.2 & 4.40 & 1.47 & 1.300 & 10.4 & 3.49 & 0.79 & 3.300 & 32.3 & 4.33 & 0.25 \\
\hline 1.800 & 20.2 & 4.00 & 0.98 & 1.350 & 10.8 & 3.54 & 0.81 & & & & \\
\hline 1.900 & 21.3 & 4.42 & 1.05 & 1.450 & 11.6 & 3.50 & 0.76 & \multirow{3}{*}{\multicolumn{4}{|c|}{$\begin{array}{l}\text { Source: Duplessy [1982] } \\
\text { Species. C. wuellerstorfi }\end{array}$}} \\
\hline 2.200 & 24.4 & 3.93 & 0.76 & 1.500 & 12.3 & 4.14 & 0.41 & & & & \\
\hline 2.300 & 25.5 & 3.68 & 0.22 & 1.550 & 13.0 & 3.96 & 0.59 & & & & \\
\hline
\end{tabular}




\begin{tabular}{|c|c|c|c|}
\hline Depth, m & Age, kyr & $\delta^{18} \mathrm{O}$ & ${ }^{\delta^{13}} \mathrm{C}$ \\
\hline \multicolumn{4}{|c|}{$\begin{array}{l}\text { Core: CHN82-24 } \\
43^{\circ} \mathrm{N} 30^{\circ} \mathrm{W} \\
3070 \mathrm{~m}\end{array}$} \\
\hline 0.040 & 0.4 & 2.69 & 1.11 \\
\hline 0.040 & 0.4 & 2.68 & 0.99 \\
\hline 0.070 & 1.3 & 2.66 & 0.85 \\
\hline 0.100 & 2.2 & 2.61 & 1.27 \\
\hline 0.100 & 2.2 & 2.58 & 1.01 \\
\hline 0.130 & 3.1 & 2.59 & 1.29 \\
\hline 0.130 & 3.1 & 2.63 & 1.03 \\
\hline 0.190 & 4.9 & 2.69 & 0.91 \\
\hline 0.220 & 5.9 & 2.67 & 1.04 \\
\hline 0.250 & 6.8 & 2.84 & 1.05 \\
\hline 0.250 & 6.8 & 3.00 & 0.87 \\
\hline 0.330 & 9.2 & 3.13 & 0.88 \\
\hline 0.545 & 13.6 & 4.16 & 0.67 \\
\hline 0.590 & 14.3 & 4.37 & 0.42 \\
\hline 0.620 & 14.7 & 4.40 & 0.48 \\
\hline 0.650 & 15.5 & 4.41 & 0.53 \\
\hline 0.730 & 18.6 & 4.08 & 0.48 \\
\hline 0.750 & 19.3 & 4.09 & 0.59 \\
\hline 0.830 & 22.4 & 4.08 & 0.70 \\
\hline 0.910 & 25.5 & 3.96 & 0.60 \\
\hline 0.970 & 27.8 & 3.77 & 0.76 \\
\hline 1.100 & 32.9 & 3.93 & 1.00 \\
\hline 1.165 & 35.4 & 3.81 & 0.63 \\
\hline 1.190 & 36.3 & 4.02 & 1.23 \\
\hline 1.260 & 39.1 & 3.78 & 0.95 \\
\hline 1.300 & 40.6 & 3.69 & 0.93 \\
\hline 1.330 & 41.8 & 3.93 & 0.86 \\
\hline 1.385 & 43.9 & 3.42 & 0.89 \\
\hline
\end{tabular}

Source Boyle and Kelgwin [1985/86]

Species' C. wuellerstorf, C. kullenbergi

$\overline{\text { Depth, } m \quad \text { Age, kyr } \quad \delta^{18} \mathrm{O} \quad \delta^{13} \mathrm{C}}$

\section{Core: V26-176 \\ $36^{\circ} \mathrm{N} 72^{\circ} \mathrm{W}$}

$3942 \mathrm{~m}$

$\begin{array}{llll}0.000 & 0.0 & 2.54 & 1.15 \\ 0.100 & 0.6 & 2.53 & 1.04 \\ 0.200 & 1.2 & 3.05 & 1.14 \\ 0.300 & 1.8 & 2.72 & 0.84 \\ 0.390 & 2.3 & 2.69 & 0.62 \\ 0.500 & 3.0 & 2.48 & 0.63 \\ 0.600 & 3.6 & 2.73 & 0.90 \\ 0.770 & 4.6 & 2.88 & 0.66 \\ 1.000 & 6.0 & 2.80 & 1.45 \\ 1.100 & 6.6 & 2.96 & 1.16 \\ 1.290 & 7.8 & 2.63 & 0.79 \\ 1.400 & 8.4 & 1.68 & 2.81 \\ 1.400 & 8.4 & 2.81 & 1.23\end{array}$

\begin{tabular}{cccc}
\hline & & & \\
\hline & & & \\
& & & \\
\hline & & & \\
1.450 & 8.7 & 2.46 & 1.01 \\
1.500 & 9.0 & 2.61 & 1.08 \\
1.600 & 9.6 & 2.57 & 1.11 \\
1.690 & 10.2 & 2.95 & 1.33 \\
1.800 & 10.9 & 2.74 & 0.95 \\
2.010 & 11.8 & 3.31 & 0.74 \\
2.110 & 12.0 & 3.33 & 0.84 \\
2.200 & 12.2 & 3.45 & 0.40 \\
2.300 & 12.4 & 3.50 & 0.66 \\
2.390 & 12.6 & 3.20 & 0.60 \\
2.620 & 13.0 & 3.53 & 0.08 \\
3.200 & 14.1 & 3.51 & 0.60 \\
3.470 & 14.6 & 4.01 & 0.03 \\
3.710 & 15.4 & 4.17 & 0.52 \\
3.810 & 16.8 & 3.56 & 0.90 \\
3.920 & 18.4 & 4.05 & 0.18 \\
4.280 & 23.4 & 3.76 & 0.55 \\
4.690 & 29.2 & 3.45 & 0.35 \\
4.790 & 30.6 & 3.70 & 0.17 \\
4.980 & 33.2 & 2.61 & 1.15 \\
5.080 & 34.6 & 3.69 & 0.24 \\
5.180 & 36.0 & 3.77 & 0.31 \\
5.320 & 38.0 & 4.07 & 0.63 \\
5.430 & 39.6 & 3.99 & -0.51 \\
& & & \\
\hline & & & \\
\hline
\end{tabular}

Source: Kergwin [unpublished data]

Species. C. wuellerstorfi, C. kullenbergi

\begin{tabular}{|c|c|c|c|}
\hline Depth, m & Age, kyr & $\delta^{18} \mathrm{O}$ & $\delta^{13} \mathrm{C}$ \\
\hline \multicolumn{4}{|c|}{$\begin{array}{l}\text { Core: CH75-04 } \\
10^{\circ} \mathrm{N} 56^{\circ} \mathrm{W} \\
3820 \mathrm{~m}\end{array}$} \\
\hline $\begin{array}{l}0.000 \\
0.125 \\
0.425 \\
0.525 \\
0.613 \\
0.637 \\
0.687 \\
0.962 \\
1.087 \\
1.175 \\
1.288 \\
1.375 \\
1.475\end{array}$ & $\begin{array}{c}0.0 \\
4.0 \\
7.5 \\
8.6 \\
9.6 \\
9.9 \\
10.4 \\
15.1 \\
16.6 \\
17.8 \\
19.2 \\
20.3 \\
21.6\end{array}$ & $\begin{array}{l}2.82 \\
3.20 \\
3.07 \\
3.31 \\
3.75 \\
3.84 \\
3.14 \\
4.60 \\
4.48 \\
4.48 \\
4.58 \\
4.60 \\
4.56\end{array}$ & $\begin{array}{r}0.86 \\
0.48 \\
0.56 \\
0.52 \\
0.62 \\
0.49 \\
0.51 \\
0.08 \\
-0.03 \\
-0.02 \\
-0.05 \\
-0.41 \\
-0.17\end{array}$ \\
\hline \multicolumn{4}{|c|}{$\begin{array}{l}\text { Source: Duplessy [unpublıshed data] } \\
\text { Species: Cabıcsdoides spp. }\end{array}$} \\
\hline Depth, m & Age, kyr & $\delta^{18} \mathrm{O}$ & $\delta^{13} \mathrm{C}$ \\
\hline
\end{tabular}

Core: CH75-03 $10^{\circ} \mathrm{N} 57^{\circ} \mathrm{W}$

$3410 \mathrm{~m}$

\begin{tabular}{cccc}
0.013 & 0.4 & 2.88 & 0.89 \\
0.075 & 2.3 & 2.77 & 0.84 \\
0.150 & 6.8 & 2.99 & 0.78 \\
0.225 & 8.5 & 3.33 & 0.55 \\
0.512 & 11.4 & 3.58 & 0.76 \\
0.837 & 15.1 & 4.68 & 0.04 \\
0.937 & 17.5 & 4.65 & 0.31 \\
1.237 & 24.6 & 4.25 & 0.48 \\
1.268 & 25.3 & 4.28 & 0.39 \\
1.450 & 29.6 & 4.69 & 0.04 \\
1.487 & 30.5 & 4.64 & 0.15 \\
\hline
\end{tabular}

Source: Duplessy [unpublished data]

Species: Ctbicidoides spp.

$40^{\circ} \mathrm{N} 22^{\circ} \mathrm{W}$

$3485 \mathrm{~m}$

\begin{tabular}{cccc}
0.000 & 0.0 & 2.92 & 0.90 \\
0.040 & 2.2 & 3.00 & 0.90 \\
0.100 & 5.4 & 2.76 & 0.92 \\
0.250 & 13.1 & 3.78 & 0.75 \\
0.300 & 15.1 & 4.27 & 0.80 \\
0.350 & 16.5 & 4.29 & 0.82 \\
0.400 & 18.0 & 4.24 & 0.70 \\
0.520 & 21.4 & 4.16 & 0.84 \\
0.600 & 23.7 & 4.00 & 0.92 \\
\hline
\end{tabular}

Source: Duplessy [unpublished data]

Species. Crbicrdordes spp.
Depth, m Age, kyr $\quad \delta^{18} \mathrm{O} \quad \delta^{13} \mathrm{C}$

Core: CH74-227

$35^{\circ} \mathrm{N} 29^{\circ} \mathrm{W}$

$3225 \mathrm{~m}$

$\begin{array}{llll}0.300 & 5.0 & 3.27 & 0.46 \\ 0.400 & 6.7 & 3.27 & 0.86\end{array}$




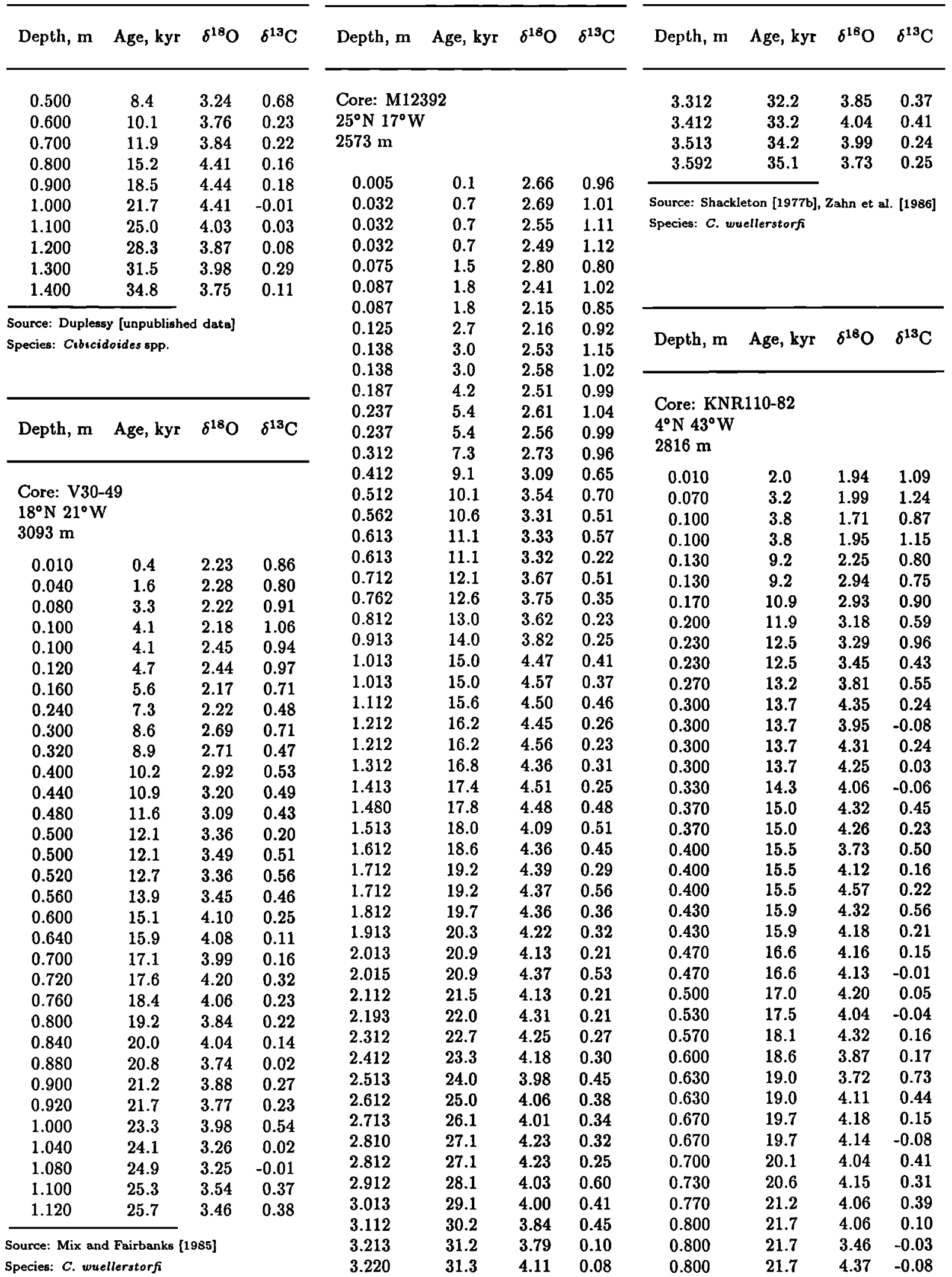




\begin{tabular}{|c|c|c|c|c|c|c|c|c|c|c|c|}
\hline Depth, m & Age, kyr & $\delta^{18} \mathrm{O}$ & $\delta^{13} \mathrm{C}$ & Depth, In & Age, kyr & $\delta^{18} \mathrm{O}$ & $\delta^{13} \mathrm{C}$ & Depth, m & Age, kyr & $\delta^{18} \mathrm{O}$ & $\delta^{13} \mathrm{C}$ \\
\hline 0.830 & 22.1 & 4.12 & 0.47 & 0.400 & 16.2 & 3.90 & 0.47 & \multicolumn{2}{|c|}{ Core: KNR110-71 } & & \\
\hline 0.870 & 22.7 & 3.99 & 0.55 & 0.430 & 16.7 & 4.10 & 0.30 & \multicolumn{2}{|c|}{$4^{\circ} \mathrm{N} 44^{\circ} \mathrm{W}$} & & \\
\hline 0.900 & 23.2 & 4.00 & 0.54 & 0.430 & 16.7 & 3.87 & 0.85 & \multicolumn{2}{|l|}{$3164 \mathrm{~m}$} & & \\
\hline 0.930 & 23.7 & 3.80 & 0.59 & 0.430 & 16.7 & 4.23 & 0.19 & & & & \\
\hline 0.970 & 24.3 & 3.75 & 0.64 & 0.470 & 17.4 & 3.26 & -0.04 & 0.010 & 1.1 & 2.44 & 1.20 \\
\hline 0.970 & 24.3 & 3.15 & 0.44 & 0.470 & 17.4 & 3.79 & 0.01 & 0.010 & 1.1 & 2.16 & 1.22 \\
\hline 1.000 & 24.8 & 3.24 & 0.62 & 0.470 & 17.4 & 4.16 & 0.16 & 0.010 & 1.1 & 2.35 & 1.20 \\
\hline 1.000 & 24.8 & 3.62 & 0.07 & 0.500 & 17.9 & 3.85 & 0.41 & 0.070 & 3.5 & 2.22 & 0.99 \\
\hline 1.030 & 25.2 & 3.77 & 0.65 & 0.530 & 18.4 & 3.76 & 0.30 & 0.070 & 3.5 & 2.19 & 0.98 \\
\hline 1.030 & 25.2 & 3.26 & 0.66 & 0.570 & 19.1 & 3.95 & 0.38 & 0.100 & 7.0 & 2.68 & 1.36 \\
\hline 1.070 & 25.8 & 3.58 & 0.48 & 0.600 & 19.6 & 3.78 & 0.48 & 0.100 & 7.0 & 2.20 & 0.66 \\
\hline 1.100 & 26.3 & 3.65 & 0.58 & 0.630 & 20.1 & 3.65 & 0.19 & 0.100 & 7.0 & 2.56 & 1.39 \\
\hline 1.100 & 26.3 & 3.80 & 0.48 & 0.630 & 20.1 & 3.26 & -0.29 & 0.130 & 9.2 & 2.57 & 1.37 \\
\hline 1.130 & 26.8 & 3.18 & 0.31 & 0.630 & 20.1 & 3.95 & 0.39 & 0.130 & 9.2 & 3.18 & 0.76 \\
\hline 1.130 & 26.8 & 3.90 & 0.71 & 0.670 & 20.7 & 3.60 & 0.22 & 0.130 & 9.2 & 3.11 & 1.07 \\
\hline 1.130 & 26.8 & 4.04 & 0.70 & 0.670 & 20.7 & 3.60 & 0.19 & 0.170 & 10.4 & 3.13 & 0.91 \\
\hline 1.170 & 27.4 & 3.35 & 0.67 & 0.700 & 21.3 & 3.65 & 0.30 & 0.170 & 10.4 & 2.89 & 0.36 \\
\hline 1.200 & 27.8 & 3.53 & 0.86 & 0.730 & 21.8 & 3.69 & 0.34 & 0.200 & 11.3 & 2.96 & 0.75 \\
\hline 1.230 & 28.3 & 3.62 & 1.12 & 0.770 & 22.4 & 3.91 & 0.42 & 0.230 & 12.2 & 3.62 & 0.28 \\
\hline 1.230 & 28.3 & 3.78 & 0.85 & 0.800 & 23.0 & 3.98 & 0.72 & 0.230 & 12.2 & 3.39 & 0.28 \\
\hline 1.270 & 28.9 & 3.40 & 0.80 & 0.830 & 23.5 & 2.84 & 0.13 & 0.270 & 13.3 & 3.53 & 0.73 \\
\hline 1.300 & 29.4 & 3.75 & 0.71 & 0.870 & 24.1 & 3.65 & 0.60 & 0.300 & 14.2 & 4.41 & 0.64 \\
\hline 1.300 & 29.4 & 3.87 & 0.95 & 0.870 & 24.1 & 3.70 & 0.75 & 0.300 & 14.2 & 3.74 & 0.34 \\
\hline 1.330 & 29.9 & 3.33 & 0.65 & 0.900 & 24.6 & 3.75 & 0.60 & 0.330 & 15.0 & 4.33 & 0.48 \\
\hline \multirow[t]{2}{*}{1.330} & 29.9 & 3.69 & 0.67 & 0.930 & 25.2 & 3.65 & 0.72 & 0.370 & 15.9 & 4.19 & 0.51 \\
\hline & & & & 0.970 & 25.8 & 3.70 & 0.64 & 0.370 & 15.9 & 4.20 & 0.43 \\
\hline \multicolumn{4}{|c|}{ Source: Curry and Lohmann [in manuscript] } & 1.000 & 26.3 & 3.80 & 0.77 & 0.400 & 16.6 & 4.07 & 0.28 \\
\hline \multirow{3}{*}{\multicolumn{4}{|c|}{ Species: $C$. wuellerstorf }} & 1.000 & 26.3 & 3.59 & 0.60 & 0.430 & 17.2 & 3.84 & 0.34 \\
\hline & & & & 1.030 & 26.9 & 3.37 & 0.56 & 0.470 & 18.1 & 3.12 & -0.01 \\
\hline & & & & 1.070 & 27.5 & 2.89 & 0.44 & 0.470 & 18.1 & 3.86 & 0.47 \\
\hline \multirow{3}{*}{ Depth, m } & \multirow{3}{*}{ Age, kyr } & \multirow{3}{*}{$\delta^{18} \mathrm{O}$} & \multirow{3}{*}{$\delta^{13} \mathrm{C}$} & 1.070 & 27.5 & 3.60 & 0.63 & 0.500 & 18.8 & 3.66 & 0.28 \\
\hline & & & & 1.070 & 27.5 & 3.99 & 0.65 & 0.530 & 19.4 & 4.24 & 0.56 \\
\hline & & & & 1.070 & 27.5 & 3.68 & 0.67 & 0.570 & 20.3 & 3.95 & 0.37 \\
\hline \multirow{2}{*}{\multicolumn{2}{|c|}{ Core: KNR110-75 }} & & & 1.100 & 28.0 & 3.67 & 0.42 & 0.570 & 20.3 & 3.54 & 0.85 \\
\hline & & & & 1.130 & 28.6 & 3.22 & 0.81 & 0.600 & 21.0 & 4.11 & 0.44 \\
\hline \multicolumn{2}{|c|}{$4^{\circ} \mathrm{N} 43^{\circ} \mathrm{W}$} & & & 1.130 & 28.6 & 4.11 & 0.35 & 0.630 & 21.7 & 4.06 & 0.34 \\
\hline \multirow{2}{*}{$3063 \mathrm{~m}$} & & & & 1.170 & 29.2 & 4.04 & 0.59 & 0.630 & 21.7 & 3.84 & 0.37 \\
\hline & & & & 1.200 & 29.7 & 3.86 & 1.18 & 0.670 & 22.5 & 3.60 & 0.17 \\
\hline 0.010 & 0.2 & 2.52 & 0.41 & 1.200 & 29.7 & 3.68 & 1.04 & 0.700 & 23.2 & 3.69 & 0.76 \\
\hline 0.010 & 0.2 & 2.43 & 1.20 & 1.200 & 29.7 & 3.97 & 0.84 & 0.700 & 23.2 & 3.61 & 0.53 \\
\hline 0.070 & 1.7 & 2.35 & 1.02 & 1.230 & 30.2 & 3.36 & 0.58 & 0.730 & 23.9 & 3.80 & 0.49 \\
\hline 0.070 & 1.7 & 2.78 & 1.49 & 1.270 & 30.9 & 3.44 & 0.84 & 0.770 & 24.9 & 3.46 & 0.33 \\
\hline 0.100 & 2.5 & 2.33 & 0.84 & 1.300 & 31.4 & 3.46 & 0.70 & 0.800 & 25.6 & 3.70 & 0.50 \\
\hline 0.130 & 5.1 & 2.03 & 0.54 & 1.330 & 31.9 & 3.67 & 0.92 & 0.830 & 26.4 & 3.61 & 0.77 \\
\hline 0.130 & 5.1 & 2.68 & 1.36 & 1.330 & 31.9 & 3.86 & 0.70 & 0.830 & 26.4 & 4.26 & 0.60 \\
\hline 0.170 & 9.5 & 3.02 & 0.32 & & & & & 0.870 & 27.4 & 3.75 & 0.52 \\
\hline 0.200 & 11.3 & 2.92 & 0.50 & \multirow{2}{*}{\multicolumn{4}{|c|}{ Source: Curry and Lohmann [in manuscript] }} & 0.900 & 28.1 & 3.62 & 0.67 \\
\hline 0.230 & 13.4 & 4.01 & 0.65 & & & & & 0.900 & 28.1 & 4.12 & 0.71 \\
\hline 0.230 & 13.4 & 3.96 & 0.36 & Species: $C . \psi$ & uellerstorfi & & & 0.930 & 28.8 & 3.55 & 0.67 \\
\hline 0.270 & 14.0 & 3.67 & 0.28 & & & & & 0.970 & 29.8 & 3.49 & 0.69 \\
\hline 0.270 & 14.0 & 3.90 & 0.07 & & & & & 1.000 & 30.6 & 4.00 & 0.73 \\
\hline 0.300 & 14.5 & 3.11 & -0.43 & & & & & 1.000 & 30.6 & 3.38 & 0.49 \\
\hline 0.300 & 14.5 & 3.36 & -0.03 & & & & & 1.000 & 30.6 & 4.13 & 0.87 \\
\hline 0.300 & 14.5 & 4.02 & 0.14 & & & & & 1.030 & 31.3 & 3.96 & 0.84 \\
\hline 0.330 & 15.0 & 4.01 & 0.47 & & & & & 1.070 & 32.3 & 3.46 & 0.54 \\
\hline 0.330 & 15.0 & 4.00 & -0.24 & & & & & 1.100 & 33.1 & 3.91 & 0.56 \\
\hline 0.370 & 15.7 & 3.96 & 0.34 & & & & & 1.130 & 33.8 & 3.56 & 0.81 \\
\hline
\end{tabular}




\begin{tabular}{|c|c|c|c|c|c|c|c|c|c|c|c|}
\hline Depth, m & Age, kyr & $\delta^{18} O$ & $\delta^{13} \mathrm{C}$ & Depth, m & Age, kyr & $\delta^{18} \mathrm{O}$ & $\delta^{13} \mathrm{C}$ & Depth, m & Age, kyr & $\delta^{18} \mathrm{O}$ & $\delta^{13} \mathrm{C}$ \\
\hline 1.170 & 34.8 & 3.48 & 0.77 & 0.630 & 17.2 & 3.58 & 0.21 & 0.230 & 13.6 & 3.63 & -0.21 \\
\hline 1.200 & 35.6 & 3.59 & 0.94 & 0.670 & 18.0 & 3.27 & -0.07 & 0.270 & 14.4 & 3.58 & -0.37 \\
\hline 1.230 & 36.3 & 3.42 & 1.04 & 0.700 & 10.6 & 3.86 & 0.39 & 0.270 & 14.4 & 4.47 & 0.22 \\
\hline 1.270 & 37.3 & 3.58 & 0.47 & 0.730 & 19 , & 3.38 & -0.05 & 0.270 & 14.4 & 4.05 & 0.30 \\
\hline 1.300 & 38.0 & 3.82 & 0.78 & 0.770 & $2 \leq 1$ & 4.06 & 0.21 & 0.270 & 14.4 & 4.39 & 0.04 \\
\hline 1.330 & 38.8 & 3.10 & 0.49 & 0.800 & 20.7 & 4.06 & 0.33 & 0.300 & 15.0 & 4.03 & -0.10 \\
\hline 1.370 & 39.8 & 3.82 & 0.75 & 0.830 & 21.3 & 3.82 & 0.32 & 0.300 & 15.0 & 4.37 & 0.08 \\
\hline 1.400 & 40.5 & 3.91 & 1.27 & 0.870 & 22.2 & 3.77 & 0.56 & 0.300 & 15.0 & 4.48 & 0.06 \\
\hline 1.430 & 41.3 & 3.83 & 0.96 & 0.900 & 22.8 & 4.01 & 0.36 & 0.330 & 15.8 & 4.14 & -0.10 \\
\hline \multirow[t]{2}{*}{1.470} & 42.3 & 4.01 & 0.89 & 0.930 & 23.4 & 3.65 & 0.28 & 0.330 & 15.8 & 4.29 & 0.28 \\
\hline & & & & 0.930 & 23.4 & 3.32 & -0.35 & 0.330 & 15.8 & 4.03 & 0.35 \\
\hline \multicolumn{4}{|c|}{ Source: Curry and Lohmann [in manuscript] } & 0.970 & 24.2 & 3.52 & 0.17 & 0.370 & 16.8 & 3.75 & -0.13 \\
\hline Species: $C . w u$ & Herstorfi & & & 1.000 & 24.9 & 4.11 & 0.76 & 0.370 & 16.8 & 4.43 & 0.30 \\
\hline & & & & 1.000 & 24.9 & 3.72 & 0.74 & 0.400 & 17.6 & 3.30 & 0.07 \\
\hline & & & & 1.030 & 25.5 & 3.23 & 0.13 & 0.400 & 17.6 & 4.75 & 0.67 \\
\hline & & & & 1.030 & 25.5 & 3.15 & 0.05 & 0.400 & 17.6 & 4.17 & 0.29 \\
\hline & & & & 1.070 & 26.3 & 3.30 & 0.26 & 0.400 & 17.6 & 4.13 & 0.04 \\
\hline Depth, m & Age, kyr & $\delta^{18} \mathrm{O}$ & $\delta^{13} \mathrm{C}$ & 1.100 & 26.9 & 3.50 & 0.34 & 0.430 & 18.3 & 3.71 & 0.07 \\
\hline Dopoin, iा & 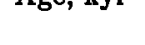 & & & 1.130 & 27.6 & 3.95 & 0.62 & 0.470 & 19.4 & 3.72 & 0.02 \\
\hline & & & & 1.170 & 28.4 & 4.40 & 0.82 & 0.470 & 19.4 & 3.97 & 0.40 \\
\hline Core: KNR & $110-66$ & & & 1.170 & 28.4 & 3.51 & 0.18 & 0.500 & 20.1 & 3.68 & -0.08 \\
\hline $5^{\circ} \mathrm{N} 43^{\circ} \mathrm{W}$ & & & & 1.200 & 29.0 & 3.28 & 0.38 & 0.530 & 20.9 & 3.65 & -0.12 \\
\hline $3547 \mathrm{~m}$ & & & & 1.230 & 29.6 & 3.84 & 0.66 & 0.570 & 21.9 & 3.73 & -0.04 \\
\hline 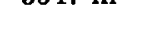 & & & & 1.270 & 30.5 & 3.28 & 0.70 & 0.570 & 21.9 & 4.01 & 0.25 \\
\hline 0.000 & 0.0 & 1.99 & 0.90 & 1.270 & 30.5 & 4.46 & 0.94 & 0.600 & 22.7 & 3.90 & 0.25 \\
\hline 0.000 & 0.0 & 2.33 & 0.64 & 1.270 & 30.5 & 3.79 & -0.01 & 0.600 & 22.7 & 4.13 & 0.02 \\
\hline 0.000 & 0.0 & 2.44 & 0.88 & 1.300 & 31.1 & 3.85 & 0.23 & 0.630 & 23.5 & 3.47 & -0.03 \\
\hline 0.000 & 0.0 & 2.42 & 0.90 & 1.300 & 31.1 & 4.19 & 0.62 & 0.630 & 23.5 & 3.96 & 0.32 \\
\hline 0.070 & 1.4 & 1.80 & 0.96 & 1.300 & 31.1 & 3.95 & 0.89 & 0.670 & 24.6 & 3.76 & 0.24 \\
\hline 0.070 & 1.4 & 2.46 & 0.88 & 1.330 & 31.7 & 3.38 & 0.56 & 0.700 & 25.5 & 3.95 & 0.28 \\
\hline 0.070 & 1.4 & 2.42 & 0.90 & 1.330 & 31.7 & 4.00 & 0.85 & 0.730 & 26.3 & 3.97 & 0.28 \\
\hline 0.100 & 2.0 & 1.63 & 0.04 & & & & & 0.770 & 27.5 & 3.79 & 0.51 \\
\hline 0.100 & 2.0 & 2.25 & 1.03 & Source. Curry & and Lohmann & {$[1983,19$} & 885] & 0.770 & 27.5 & 3.53 & 0.23 \\
\hline 0.100 & 2.0 & 2.51 & 0.98 & Species $C$. wu & ellerstorf & & & 0.800 & 28.3 & 3.57 & 0.11 \\
\hline 0.130 & 2.6 & 1.98 & 0.43 & & & & & 0.830 & 29.2 & 3.46 & -0.06 \\
\hline 0.170 & 5.9 & 1.89 & 0.56 & & & & & 0.830 & 29.2 & 4.33 & 0.10 \\
\hline 0.170 & 5.9 & 2.29 & 1.18 & & & & & 0.830 & 29.2 & 3.95 & 0.33 \\
\hline 0.200 & 7.3 & 2.97 & 0.40 & & & & & 0.870 & 30.4 & 3.83 & 0.31 \\
\hline 0.200 & 7.3 & 2.68 & 1.01 & Depth, m & Age, kyr & $\delta^{18} \mathrm{O}$ & $\delta^{13} \mathrm{C}$ & 0.900 & 31.2 & 3.88 & 0.47 \\
\hline 0.230 & 8.1 & 2.46 & 0.79 & & & & & 0.930 & 32.1 & 4.07 & 0.77 \\
\hline 0.230 & 8.1 & 2.34 & 0.33 & & & & & 0.930 & 32.1 & 3.73 & 0.33 \\
\hline 0.270 & 9.1 & 2.72 & 0.59 & Core: KNR & $110-91$ & & & 0.970 & 33.2 & 3.47 & 0.47 \\
\hline 0.300 & 10.1 & 3.54 & 0.04 & $5^{\circ} \mathrm{N} 43^{\circ} \mathrm{W}$ & & & & 1.000 & 34.1 & 3.48 & 0.44 \\
\hline 0.300 & 10.1 & 3.29 & 0.35 & $3810 \mathrm{~m}$ & & & & 1.030 & 34.9 & 3.94 & 0.73 \\
\hline 0.330 & 11.1 & 2.76 & -0.25 & & & & & 1.030 & 34.9 & 4.20 & 0.30 \\
\hline 0.330 & 11.1 & 3.28 & 0.75 & 0.020 & 1.4 & 2.27 & 0.86 & 1.070 & 36.1 & 3.68 & 0.43 \\
\hline 0.370 & 11.9 & 3.15 & -0.12 & 0.020 & 1.4 & 2.39 & 0.93 & 1.100 & 36.9 & 3.49 & 0.63 \\
\hline 0.400 & 12.5 & 3.65 & -0.01 & 0.070 & 1.9 & 2.40 & 0.86 & 1.130 & 37.8 & 3.50 & 0.56 \\
\hline 0.430 & 13.1 & 3.66 & 0.03 & 0.070 & 1.9 & 2.19 & 0.82 & 1.130 & 37.8 & 3.68 & 0.27 \\
\hline 0.470 & 13.9 & 3.54 & -0.15 & 0.100 & 3.5 & 2.29 & 0.31 & 1.170 & 39.0 & 3.77 & 0.34 \\
\hline 0.500 & 14.5 & 3.96 & 0.22 & 0.100 & 3.5 & 2.13 & 0.52 & 1.200 & 39.8 & 3.79 & 0.53 \\
\hline 0.530 & 15.1 & 4.44 & 0.48 & 0.130 & 10.0 & 2.77 & 0.50 & 1.270 & 41.8 & 3.61 & 0.49 \\
\hline 0.530 & 15.1 & 4.20 & 0.43 & 0.130 & 10.0 & 3.35 & 0.68 & 1.300 & 42.7 & 3.62 & 0.57 \\
\hline 0.530 & 15.1 & 4.10 & 0.27 & 0.130 & 10.0 & 2.82 & 0.53 & 1.300 & 42.7 & 3.59 & 0.26 \\
\hline 0.570 & 15.9 & 3.63 & 0.35 & 0.130 & 10.0 & 3.13 & 0.15 & 1.330 & 43.5 & 3.58 & 0.47 \\
\hline 0.570 & 15.9 & 3.94 & 0.42 & 0.170 & 12.4 & 3.81 & 0.20 & & & & \\
\hline 0.600 & 16.6 & 4.21 & 0.27 & 0.200 & 13.0 & 3.73 & 0.22 & Source Curr & dd Lohman & [in manu & script] \\
\hline 0.600 & 16.6 & 4.00 & 0.48 & 0.200 & 13.0 & 3.39 & 0.41 & Species $c$. & Uerstorfi & & \\
\hline
\end{tabular}




\begin{tabular}{|c|c|c|c|c|c|c|c|c|c|c|c|}
\hline Depth, m & Age, kyr & $\delta^{18} \mathrm{O}$ & $\delta^{13} \mathrm{C}$ & Depth, m & Age, kyr & $\delta^{18} \mathrm{O}$ & $\delta^{13} \mathrm{C}$ & Depth, m & Age, kyr & $\delta^{18} \mathrm{O}$ & $\delta^{13} \mathrm{C}$ \\
\hline \multicolumn{4}{|c|}{ Core: KNR110-50 } & 1.100 & 29.5 & 3.59 & 0.68 & 0.470 & 18.3 & 4.10 & -0.14 \\
\hline \multicolumn{4}{|c|}{$5^{\circ} \mathrm{N} 43^{\circ} \mathrm{W}$} & 1.130 & 30.0 & 4.29 & 0.76 & 0.500 & 19.0 & 4.19 & 0.00 \\
\hline \multirow[t]{2}{*}{$3995 \mathrm{~m}$} & & & & 1.130 & 30.0 & 3.78 & 0.43 & 0.530 & 19.7 & 3.74 & -0.15 \\
\hline & & & & 1.170 & 30.7 & 3.71 & 0.55 & 0.570 & 20.7 & 4.11 & 0.00 \\
\hline 0.010 & 0.1 & 2.46 & 0.58 & 1.200 & 31.2 & 3.80 & 0.33 & 0.600 & 21.3 & 4.14 & 0.07 \\
\hline 0.010 & 0.1 & 2.45 & 0.94 & 1.230 & 31.7 & 3.23 & 0.37 & 0.630 & 22.0 & 4.15 & 0.19 \\
\hline 0.070 & 1.8 & 2.48 & 0.68 & 1.230 & 31.7 & 4.26 & 0.49 & 0.670 & 23.0 & 3.99 & -0.03 \\
\hline 0.070 & 1.8 & 3.00 & 1.21 & 1.230 & 31.7 & 4.05 & 0.34 & 0.730 & 24.6 & 3.84 & 0.20 \\
\hline 0.100 & 4.5 & 2.26 & 0.23 & 1.270 & 32.3 & 3.65 & 0.60 & 0.770 & 25.9 & 3.77 & 0.14 \\
\hline 0.100 & 4.5 & 1.82 & 0.47 & 1.300 & 32.8 & 3.74 & 0.60 & 0.770 & 25.9 & 3.89 & -0.06 \\
\hline 0.100 & 4.5 & 3.09 & 0.03 & 1.330 & 33.3 & 3.89 & 0.75 & 0.800 & 26.8 & 4.03 & 0.16 \\
\hline 0.130 & 10.3 & 3.13 & 0.31 & 1.330 & 33.3 & 4.07 & 0.65 & 0.830 & 27.8 & 4.08 & 0.21 \\
\hline 0.130 & 10.3 & 3.71 & 0.23 & \multirow{2}{*}{\multicolumn{4}{|c|}{ Source Curry and Lohmann [in manuscript] }} & 0.870 & 29.0 & 3.35 & 0.12 \\
\hline 0.170 & 11.5 & 3.23 & -0.05 & & & & & 0.870 & 29.0 & 3.87 & 0.27 \\
\hline 0.170 & 11.5 & 3.41 & -0.25 & \multicolumn{4}{|c|}{ Speciea: $C$. wuellerstorfi } & 0.870 & 29.0 & 3.43 & 0.46 \\
\hline 0.200 & 13.4 & 3.78 & -0.25 & & & & & 0.870 & 29.0 & 3.67 & 0.08 \\
\hline 0.230 & 15.1 & 4.26 & 0.10 & & & & & 0.900 & 30.0 & 3.90 & 0.35 \\
\hline 0.230 & 15.1 & 4.32 & 0.09 & & & & & 0.930 & 30.9 & 3.76 & 0.26 \\
\hline 0.270 & 15.7 & 3.95 & -0.01 & & & & & 1.000 & 33.1 & 3.75 & 0.24 \\
\hline 0.300 & 16.2 & 3.95 & -0.01 & Depth, m & Age, $\mathbf{k y r}$ & $\delta^{18} \mathrm{O}$ & $\delta^{13} \mathrm{C}$ & 1.030 & 34.1 & 3.81 & 0.31 \\
\hline 0.300 & 16.2 & 4.22 & 0.34 & Depoin, III & Rge, nyi & & & 1.030 & 34.1 & 3.87 & 0.43 \\
\hline 0.300 & 16.2 & 4.08 & 0.18 & & & & & 1.070 & 35.4 & 3.42 & 0.09 \\
\hline 0.330 & 16.7 & 3.80 & -0.12 & Core: KNR & $2110-58$ & & & 1.070 & 35.4 & 3.77 & -0.10 \\
\hline 0.330 & 16.7 & 4.18 & 0.32 & $5^{\circ} \mathrm{N} 43^{\circ} \mathrm{W}$ & & & & 1.100 & 36.3 & 3.73 & 0.60 \\
\hline 0.370 & 17.4 & 4.03 & 0.14 & $4341 \mathrm{~m}$ & & & & 1.100 & 36.3 & 3.66 & 0.13 \\
\hline 0.400 & 17.9 & 4.13 & 0.22 & & & & & 1.130 & 37.2 & 3.48 & 0.18 \\
\hline 0.430 & 18.4 & 4.16 & 0.17 & 0.010 & 0.2 & 2.17 & 0.73 & 1.130 & 37.2 & 3.64 & 0.50 \\
\hline 0.470 & 19.1 & 4.07 & 0.28 & 0.010 & 0.2 & 2.17 & 0.20 & 1.170 & 38.5 & 3.37 & 0.22 \\
\hline 0.470 & 19.1 & 3.81 & 0.06 & 0.010 & 0.2 & 2.89 & 0.64 & 1.170 & 38.5 & 3.79 & 0.27 \\
\hline 0.500 & 19.6 & 4.01 & 0.23 & 0.030 & 0.6 & 2.61 & 0.35 & 1.200 & 39.5 & 3.31 & 0.56 \\
\hline 0.530 & 20.1 & 4.14 & 0.16 & 0.070 & 1.4 & 2.50 & 1.05 & 1.230 & 40.4 & 3.63 & 0.30 \\
\hline 0.570 & 20.7 & 4.14 & 0.12 & 0.070 & 1.4 & 2.96 & 0.89 & 1.230 & 40.4 & 4.20 & 0.10 \\
\hline 0.570 & 20.7 & 3.91 & 0.20 & 0.100 & 2.0 & 2.47 & 0.79 & 1.270 & 41.7 & 3.80 & 0.53 \\
\hline 0.600 & 21.2 & 3.49 & 0.08 & 0.100 & 2.0 & 2.79 & 0.61 & 1.300 & 42.6 & 3.51 & 0.20 \\
\hline 0.600 & 21.2 & 3.79 & 0.26 & 0.130 & 2.6 & 2.76 & 0.85 & 1.300 & 42.6 & 3.57 & 0.32 \\
\hline 0.640 & 21.9 & 4.10 & 0.38 & 0.130 & 2.6 & 2.91 & 0.37 & \multirow{2}{*}{\multicolumn{4}{|c|}{ Source Curry and Lohmann [in manuscript] }} \\
\hline 0.670 & 22.4 & 3.82 & 0.17 & 0.170 & 3.6 & 2.44 & 0.40 & & & & \\
\hline 0.670 & 22.4 & 4.02 & 0.31 & 0.170 & 3.6 & 2.54 & 0.80 & \multicolumn{4}{|c|}{ Species: $C$. wuellerstorf } \\
\hline 0.700 & 22.9 & 3.48 & 0.07 & 0.200 & 9.3 & 3.31 & 0.48 & & & & \\
\hline 0.700 & 22.9 & 3.99 & 0.15 & 0.200 & 9.3 & 3.17 & 0.28 & & & & \\
\hline 0.700 & 22.9 & 3.99 & 0.33 & 0.230 & 11.6 & 3.29 & 0.24 & & & & \\
\hline 0.730 & 23.4 & 3.67 & 0.59 & 0.230 & 11.6 & 3.32 & 0.27 & & & & \\
\hline 0.730 & 23.4 & 3.96 & -0.15 & 0.270 & 13.0 & 3.96 & 0.22 & Depth, m & Age, kyr & $\delta^{18} \mathrm{O}$ & $\delta^{13} \mathrm{C}$ \\
\hline 0.730 & 23.4 & 4.10 & 0.45 & 0.270 & 13.0 & 4.02 & -0.36 & & & & \\
\hline 0.770 & 24.0 & 3.11 & 0.16 & 0.300 & 14.1 & 3.36 & 0.24 & \multirow{2}{*}{\multicolumn{2}{|c|}{ Core: KNR110-55 }} & & \\
\hline 0.770 & 24.0 & 3.96 & 0.13 & 0.300 & 14.1 & 4.29 & 0.21 & & & & \\
\hline 0.800 & 24.5 & 3.97 & 0.08 & 0.330 & 15.1 & 4.79 & 0.51 & \multicolumn{2}{|c|}{$5^{\circ} \mathrm{N} \mathbf{4 3}^{\circ} \mathrm{W}$} & & \\
\hline 0.800 & 24.5 & 3.91 & 0.39 & 0.330 & 15.1 & 4.01 & -0.01 & \multicolumn{2}{|l|}{$4556 \mathrm{~m}$} & & \\
\hline 0.830 & 25.0 & 3.38 & 0.41 & 0.330 & 15.1 & 4.29 & 0.10 & & & & \\
\hline 0.870 & 25.7 & 3.66 & 0.20 & 0.370 & 16.0 & 4.19 & -0.05 & 0.010 & 0.3 & 2.56 & 0.61 \\
\hline 0.900 & 26.2 & 3.48 & 0.29 & 0.370 & 16.0 & 4.12 & 0.31 & 0.010 & 0.3 & 2.65 & 0.21 \\
\hline 0.930 & 26.7 & 3.30 & 0.17 & 0.370 & 16.0 & 4.01 & 0.17 & 0.010 & 0.3 & 2.57 & 0.85 \\
\hline 0.970 & 27.3 & 3.73 & 0.49 & 0.400 & 16.7 & 4.19 & 0.08 & 0.030 & 1.0 & 2.10 & -0.08 \\
\hline 1.000 & 27.8 & 3.17 & 0.17 & 0.400 & 16.7 & 4.18 & 0.09 & 0.030 & 1.0 & 3.27 & 0.54 \\
\hline 1.000 & 27.8 & 3.79 & 0.11 & 0.400 & 16.7 & 4.38 & 0.00 & 0.030 & 1.0 & 2.70 & 0.70 \\
\hline 1.030 & 28.3 & 3.86 & 0.26 & 0.430 & 17.4 & 4.02 & -0.23 & 0.070 & 2.4 & 2.16 & 0.43 \\
\hline 1.070 & 29.0 & 3.71 & 0.76 & 0.430 & 17.4 & 4.36 & -0.11 & 0.070 & 2.4 & 2.10 & -0.51 \\
\hline
\end{tabular}




\begin{tabular}{|c|c|c|c|c|c|c|c|c|c|c|c|}
\hline Depth, m & Age, kyr & $\delta^{18} \mathrm{O}$ & $\delta^{13} \mathrm{C}$ & Depth, m & Age, kyr & $\delta^{18} \mathrm{O}$ & $\delta^{13} \mathrm{C}$ & Depth, m & Age, kyr & $\delta^{18} \mathrm{O}$ & $\delta^{13} \mathrm{C}$ \\
\hline 0.070 & 2.4 & 2.09 & 0.46 & 1.230 & 35.3 & 3.76 & 0.05 & 1.025 & 29.3 & 3.68 & 0.57 \\
\hline 0.070 & 2.4 & 2.26 & 0.02 & 1.230 & 35.3 & 3.89 & 0.39 & 1.050 & 29.8 & 3.62 & 0.71 \\
\hline 0.100 & 3.6 & 2.30 & 0.54 & 1.230 & 35.3 & 3.83 & 0.56 & 1.075 & 30.2 & 3.70 & 0.61 \\
\hline 0.100 & 3.6 & 1.74 & 0.34 & 1.270 & 36.3 & 3.94 & 0.60 & 1.100 & 30.7 & 3.54 & 0.45 \\
\hline 0.100 & 3.6 & 2.72 & 0.69 & 1.270 & 36.3 & 4.02 & 0.06 & 1.125 & 31.2 & 3.76 & 0.54 \\
\hline 0.130 & 4.9 & 2.59 & 0.44 & 1.300 & 37.0 & 3.62 & 0.15 & 1.150 & 31.7 & 3.58 & 0.70 \\
\hline 0.170 & 6.7 & 3.48 & 0.32 & 1.300 & 37.0 & 4.12 & 0.55 & 1.175 & 32.2 & 3.54 & 0.56 \\
\hline 0.170 & 6.7 & 2.55 & -0.50 & 1.300 & 37.0 & 3.93 & 0.48 & 1.200 & 32.7 & 3.63 & 0.37 \\
\hline 0.170 & 6.7 & 2.56 & 0.95 & & & & & 1.225 & 33.1 & 3.69 & 0.51 \\
\hline 0.200 & 7.9 & 2.67 & 0.07 & & & & & & & & \\
\hline 0.230 & 9.2 & 2.89 & 0.66 & Source: Curry & and Lohmann & [in manu & iscript] & & & & \\
\hline 0.230 & 9.2 & 2.78 & 0.69 & Species: $C . w v$ & sellerstorfi & & & Source: Mix and & d Fairbanks [1 & 1985] & \\
\hline 0.270 & 10.5 & 3.64 & -0.04 & & & & & Species $C$. wue & ellerstorfi & & \\
\hline 0.300 & 11.1 & 3.28 & 0.50 & & & & & & & & \\
\hline 0.300 & 11.1 & 3.68 & -0.36 & & & & & & & & \\
\hline 0.330 & 11.7 & 3.70 & 0.29 & & & & & & & & \\
\hline 0.330 & 11.7 & 3.62 & 0.24 & Depth, m & Age, kyr & $\delta^{18} \mathrm{O}$ & $\delta^{13} \mathrm{C}$ & Depth, m & Age, kyr & $\delta^{18} \mathrm{O}$ & $\delta^{13} \mathrm{C}$ \\
\hline 0.370 & 15.1 & 4.51 & -0.05 & & & & & & & & \\
\hline 0.400 & 15.8 & 4.18 & 0.13 & & & & & & & & \\
\hline 0.400 & 15.8 & 3.91 & -0.34 & Core: V25- & & & & Core: V22-1 & -197 & & \\
\hline 0.400 & 15.8 & 3.94 & 0.24 & $1^{\circ} \mathrm{N} 33^{\circ} \mathrm{W}$ & & & & $14^{\circ} \mathrm{N} 10^{\circ} \mathrm{W}$ & & & \\
\hline 0.430 & 16.5 & 3.85 & 0.15 & $3824 \mathrm{~m}$ & & & & $3167 \mathrm{~m}$ & & & \\
\hline 0.470 & 17.4 & 3.97 & -0.17 & & & & & & & & \\
\hline 0.470 & 17.4 & 4.29 & 0.12 & 0.000 & 0.0 & 2.68 & 0.96 & 0.080 & 0.7 & 2.55 & 0.69 \\
\hline 0.500 & 18.1 & 4.22 & 0.22 & 0.025 & 0.9 & 2.52 & 0.81 & 0.080 & 0.7 & 2.51 & 0.46 \\
\hline 0.500 & 18.1 & 4.45 & 0.16 & 0.050 & 1.8 & 2.41 & 0.95 & 0.100 & 0.8 & 2.67 & 0.67 \\
\hline 0.530 & 18.8 & 3.38 & -0.25 & 0.075 & 2.7 & 2.63 & 0.87 & 0.150 & 1.2 & 2.70 & 0.79 \\
\hline 0.530 & 18.8 & 3.98 & -0.17 & 0.100 & 3.5 & 2.56 & 0.85 & 0.150 & 1.2 & 2.80 & 1.01 \\
\hline 0.570 & 19.8 & 3.09 & -0.30 & 0.150 & 5.3 & 2.78 & 0.99 & 0.200 & 1.6 & 2.88 & 1.08 \\
\hline 0.570 & 19.8 & 3.97 & -0.05 & 0.175 & 6.2 & 2.87 & 0.94 & 0.250 & 2.0 & 2.75 & 0.97 \\
\hline 0.600 & 20.5 & 4.07 & -0.03 & 0.200 & 7.1 & 2.75 & 0.92 & 0.250 & 2.0 & 2.60 & 0.75 \\
\hline 0.630 & 21.2 & 4.08 & 0.17 & 0.225 & 8.0 & 2.94 & 0.80 & 0.300 & 2.5 & 2.50 & 0.62 \\
\hline 0.670 & 22.1 & 3.80 & 0.06 & 0.250 & 8.8 & 2.98 & 0.95 & 0.350 & 3.6 & 2.71 & 0.90 \\
\hline 0.700 & 22.8 & 4.04 & 0.01 & 0.300 & 10.6 & 3.50 & 0.71 & 0.400 & 4.6 & 2.99 & 0.53 \\
\hline 0.730 & 23.5 & 3.74 & 0.03 & 0.325 & 11.5 & 3.08 & 0.95 & 0.450 & 5.6 & 3.12 & 0.69 \\
\hline 0.730 & 23.5 & 4.00 & 0.10 & 0.350 & 12.2 & 3.77 & 0.04 & 0.500 & 6.6 & 2.77 & 0.77 \\
\hline 0.770 & 24.5 & 3.21 & -0.27 & 0.400 & 13.7 & 3.60 & 0.37 & 0.550 & 7.1 & 3.64 & 0.37 \\
\hline 0.770 & 24.5 & 3.75 & -0.28 & 0.425 & 14.4 & 3.51 & 0.02 & 0.600 & 7.5 & 3.15 & 0.61 \\
\hline 0.800 & 25.2 & 4.37 & 0.41 & 0.450 & 15.1 & 4.30 & 0.09 & 0.650 & 8.0 & 2.70 & 1.17 \\
\hline 0.800 & 25.2 & 4.04 & -0.31 & 0.475 & 15.6 & 4.07 & 0.02 & 0.780 & 9.4 & 3.40 & 0.02 \\
\hline 0.800 & 25.2 & 4.05 & 0.19 & 0.500 & 16.2 & 4.23 & 0.14 & 0.960 & 11.4 & 3.39 & 0.36 \\
\hline 0.830 & 25.9 & 3.46 & 0.13 & 0.550 & 17.4 & 4.28 & 0.00 & 1.050 & 13.1 & 4.31 & 0.19 \\
\hline 0.830 & 25.9 & 3.67 & -0.15 & 0.600 & 18.5 & 4.29 & 0.06 & 1.150 & 15.1 & 4.56 & 0.14 \\
\hline 0.870 & 26.8 & 3.41 & 0.18 & 0.675 & 20.5 & 4.35 & 0.14 & 1.150 & 15.1 & 4.26 & 0.08 \\
\hline 0.900 & 27.5 & 3.41 & 0.02 & 0.700 & 21.8 & 4.18 & -0.13 & 1.240 & 16.3 & 4.42 & 0.25 \\
\hline 0.930 & 28.2 & 3.96 & 0.02 & 0.725 & 23.1 & 4.15 & 0.01 & 1.350 & 17.8 & 4.31 & 0.21 \\
\hline 0.930 & 28.2 & 4.21 & 0.21 & 0.750 & 24.0 & 3.93 & -0.05 & 1.450 & 19.1 & 4.41 & 0.27 \\
\hline 0.970 & 29.2 & 3.33 & 0.21 & 0.775 & 24.4 & 3.90 & 0.02 & 1.550 & 20.5 & 4.41 & 0.05 \\
\hline 0.970 & 29.2 & 3.38 & -0.08 & 0.800 & 24.9 & 3.84 & -0.05 & 1.650 & 21.8 & 4.35 & 0.18 \\
\hline 1.000 & 29.9 & 3.69 & -0.15 & 0.825 & 25.4 & 3.76 & 0.01 & 1.750 & 23.2 & 4.39 & 0.08 \\
\hline 1.030 & 30.6 & 3.50 & -0.11 & 0.850 & 25.9 & 3.80 & -0.03 & 1.850 & 24.5 & 3.97 & 0.03 \\
\hline 1.030 & 30.6 & 3.67 & 0.12 & 0.875 & 26.4 & 3.90 & 0.31 & 1.950 & 25.8 & 4.04 & 0.18 \\
\hline 1.070 & 31.5 & 3.62 & -0.01 & 0.900 & 26.9 & 3.86 & 0.23 & & & & \\
\hline 1.100 & 32.3 & 3.61 & 0.18 & 0.925 & 27.3 & 3.56 & 0.62 & \multirow{4}{*}{\multicolumn{4}{|c|}{ Source: Shackleton [unpublished data] }} \\
\hline 1.130 & 33.0 & 3.61 & 0.20 & 0.950 & 27.8 & 3.72 & 0.33 & & & & \\
\hline 1.170 & 33.9 & 3.56 & 0.27 & 0.975 & 28.3 & 3.61 & 0.51 & & & & \\
\hline 1.200 & 34.6 & 3.62 & 0.08 & 1.000 & 28.8 & 3.62 & 0.42 & & & & \\
\hline
\end{tabular}




\begin{tabular}{|c|c|c|c|c|c|c|c|c|c|c|c|}
\hline Depth, m & Age, kyr & $\delta^{18} \mathrm{O}$ & $\delta^{13} \mathrm{C}$ & Depth, m & Age, kyr & $\delta^{18} \mathrm{O}$ & $\delta^{13} \mathrm{C}$ & Depth, m & Age, kyr & $\delta^{18} \mathrm{O}$ & $\delta^{13} \mathrm{C}$ \\
\hline \multicolumn{4}{|c|}{ Core: EN066-38 } & \multicolumn{4}{|c|}{ Core: EN066-44 } & 0.470 & 26.3 & 3.79 & 0.54 \\
\hline \multicolumn{4}{|c|}{$5^{\circ} \mathrm{N} 20^{\circ} \mathrm{W}$} & \multicolumn{4}{|c|}{$5^{\circ} \mathrm{N} 22^{\circ} \mathrm{W}$} & 0.470 & 26.3 & 3.89 & 0.48 \\
\hline \multicolumn{4}{|l|}{$2931 \mathrm{~m}$} & \multicolumn{4}{|l|}{$3428 \mathrm{~m}$} & 0.500 & 27.9 & 3.79 & 0.65 \\
\hline 0.030 & 2.2 & 2.52 & 0.98 & 0.040 & 2.4 & 2.62 & 1.15 & \multicolumn{4}{|c|}{ Source: Curry and Lohmann $[1983,1985]$} \\
\hline 0.030 & 2.2 & 2.75 & 1.11 & 0.040 & 2.4 & 2.55 & 0.94 & \\
\hline 0.060 & 4.2 & 2.69 & 1.24 & 0.070 & 7.8 & 2.95 & 0.95 & \multicolumn{4}{|c|}{ Species' C. wuellerstorfi } \\
\hline 0.090 & 6.3 & 3.17 & 0.93 & 0.070 & 7.8 & 2.90 & 1.15 & & & & \\
\hline 0.090 & & 2.82 & 0.85 & 0.100 & 9.7 & 3.69 & 0.61 & \multirow{3}{*}{ Depth, m } & \multirow{3}{*}{ Age, kyr } & & \\
\hline 0.120 & 8.3 & 2.96 & 1.09 & 0.140 & 11.6 & 3.59 & 0.59 & & & \multirow{2}{*}{$\delta^{18} \mathrm{O}$} & \multirow{2}{*}{$\delta^{13} \mathrm{C}$} \\
\hline 0.160 & 11.0 & 3.17 & 0.69 & 0.170 & 15.0 & 4.40 & 0.60 & & & & \\
\hline 0.190 & 12.4 & 3.99 & 0.41 & 0.200 & 16.4 & 4.31 & 0.54 & \multirow{2}{*}{\multicolumn{2}{|c|}{ Core: EN066-21 }} & & \\
\hline 0.220 & 13.6 & 4.05 & 0.50 & 0.200 & 16.4 & 3.87 & 0.40 & & & & \\
\hline 0.260 & 15.1 & 4.23 & 0.69 & 0.240 & 18.3 & 4.36 & 0.45 & $4^{\circ} \mathrm{N} 21^{\circ} \mathrm{W}$ & & & \\
\hline 0.290 & 17.1 & 3.98 & 0.59 & 0.270 & 19.8 & 4.60 & 0.62 & $3995 \mathrm{~m}$ & & & \\
\hline 0.320 & 19.2 & 3.93 & 0.41 & 0.270 & 19.8 & 3.94 & 0.48 & & & & \\
\hline 0.350 & 21.2 & 4.00 & 0.52 & 0.300 & 21.2 & 4.71 & 0.48 & 0.030 & 2.5 & 2.50 & 0.78 \\
\hline 0.390 & 24.0 & 3.94 & 0.55 & 0.300 & 21.2 & 4.16 & 0.50 & 0.060 & 4.0 & 2.54 & 0.83 \\
\hline 0.390 & 24.0 & 3.90 & 0.60 & 0.340 & 23.1 & 4.65 & 0.75 & 0.110 & 6.5 & 2.55 & 0.90 \\
\hline 0.420 & 26.0 & 3.85 & 0.62 & 0.340 & 23.1 & 4.02 & 0.55 & 0.160 & 9.7 & 3.06 & 0.69 \\
\hline 0.460 & 28.8 & 3.89 & 0.70 & 0.370 & 24.5 & 4.14 & 0.61 & 0.200 & 12.1 & 3.42 & 0.54 \\
\hline 0.490 & 30.8 & 3.92 & 0.53 & 0.370 & 24.5 & 4.01 & 0.57 & 0.230 & 13.0 & 3.53 & 0.34 \\
\hline & & & & 0.370 & 24.5 & 3.81 & 0.53 & 0.260 & 13.9 & 3.88 & 0.17 \\
\hline Source: Curry & and Lohmann & {$[1983,19$} & & 0.400 & 25.9 & 4.04 & 0.69 & 0.300 & 15.0 & 4.09 & 0.12 \\
\hline Species. $C$. wue & ellerstorfi & & & 0.440 & 27.8 & 4.17 & 0.62 & 0.330 & 16.2 & 4.07 & 0.19 \\
\hline & & & & 0.470 & 29.3 & 3.94 & 0.71 & 0.360 & 17.4 & 3.72 & -0.02 \\
\hline & & & & 0.470 & 29.3 & 3.97 & 0.84 & 0.400 & 19.0 & 4.03 & 0.27 \\
\hline & & & & 0.470 & 29.3 & 3.82 & 0.67 & 0.430 & 20.2 & 3.98 & 0.28 \\
\hline Depth, m & Age, kyr & $\delta^{18} \mathrm{O}$ & $\delta^{13} \mathrm{C}$ & 0.470 & 29.3 & 4.01 & 0.49 & 0.460 & 21.4 & 3.97 & 0.42 \\
\hline & & & & & & & & 0.500 & 23.1 & 3.84 & 0.39 \\
\hline Core. FNOr & $66-16$ & & & Source: Curry & and Lohmann & a $[1983,1$ & 985] & 0.560 & 25.5 & 3.42 & 0.09 \\
\hline $\begin{array}{l}\text { Core: ENO } \\
5^{\circ} \mathrm{N} 21^{\circ} \mathrm{W}\end{array}$ & $66-16$ & & & Species. C. $w$ & uellerstor $f i$ & & & 0.660 & 29.5 & 3.64 & 0.55 \\
\hline $3152 \mathrm{~m}$ & & & & & & & & 0.660 & 29.5 & 3.82 & 0.43 \\
\hline 0.040 & 1.1 & 2.54 & 0.94 & & & & & Source' Curry & $y$ and Lohmenr & n $[1983,1$ & 985] \\
\hline 0.070 & 2.3 & 2.44 & 0.99 & & & & & Species $C . u$ & uellerstorfi & & \\
\hline 0.100 & 4.9 & 3.35 & 0.57 & & & & & & & & \\
\hline 0.140 & 8.4 & 2.81 & 0.95 & & & & & & & & \\
\hline 0.170 & 11.0 & 3.09 & 0.77 & Depth, m & Age, kyr & $\delta^{18} \mathrm{O}$ & $\delta^{13} \mathrm{C}$ & & & & \\
\hline 0.200 & 12.9 & 4.14 & 0.47 & & & & & & & & \\
\hline 0.240 & 15.0 & 4.38 & 0.44 & & & & & & & & \\
\hline 0.270 & 15.7 & 4.19 & 0.31 & Core: ENC & $66-10$ & & & Depth, m & Age, kyr & $\delta^{18} \mathrm{O}$ & $\delta^{13} \mathrm{C}$ \\
\hline 0.300 & 16.3 & 4.35 & 0.43 & $7^{\circ} \mathrm{N} 22^{\circ} \mathrm{W}$ & & & & & & & \\
\hline 0.340 & 17.2 & 4.38 & 0.43 & $3527 \mathrm{~m}$ & & & & & & & \\
\hline 0.370 & 17.8 & 4.30 & 0.40 & & & & & Core: ENO & $66-36$ & & \\
\hline 0.400 & 18.5 & 4.08 & 0.46 & 0.040 & 2.8 & 2.25 & 0.82 & $4^{\circ} \mathrm{N} 20^{\circ} \mathrm{W}$ & & & \\
\hline 0.440 & 19.3 & 4.13 & 0.51 & 0.070 & 5.2 & 2.49 & 0.80 & $4270 \mathrm{~m}$ & & & \\
\hline 0.440 & 19.3 & 4.15 & 0.50 & 0.100 & 7.7 & 2.69 & 0.85 & & & & \\
\hline 0.470 & 20.0 & 4.20 & 0.54 & 0.140 & 9.6 & 3.21 & 0.48 & 0.040 & 2.6 & 2.59 & 0.99 \\
\hline 0.500 & 20.6 & 4.14 & 0.44 & 0.170 & 10.9 & 2.92 & 0.55 & 0.040 & 2.6 & 2.91 & 0.51 \\
\hline 0.500 & 20.6 & 3.96 & 0.28 & 0.240 & 13.9 & 3.96 & 0.53 & 0.070 & 4.8 & 2.87 & 0.63 \\
\hline 0.600 & 22.8 & 4.02 & 0.71 & 0.270 & 15.2 & 4.02 & 0.40 & 0.100 & 7.1 & 2.99 & 0.60 \\
\hline 0.700 & 24.9 & 3.55 & 0.84 & 0.300 & 16.9 & 3.87 & 0.36 & 0.140 & 9.3 & 3.56 & 0.58 \\
\hline 0.700 & 24.9 & 3.97 & 0.81 & 0.340 & 19.1 & 4.11 & 0.19 & 0.170 & 10.7 & 3.12 & 0.75 \\
\hline & & & & 0.370 & 20.7 & 3.91 & 0.47 & 0.200 & 12.2 & 3.75 & 0.33 \\
\hline Source. Curry & d Lohmann & {$[1983,19$} & & 0.400 & 22.4 & 3.81 & 0.54 & 0.240 & 14.9 & 4.28 & 0.38 \\
\hline Species $C . w u$ & ellerstorfi & & & 0.440 & 24.6 & 3.79 & 0.44 & 0.270 & 16.3 & 4.24 & 0.19 \\
\hline
\end{tabular}




\begin{tabular}{cccc} 
Depth, m & Age, kyr & $\delta^{18} \mathrm{O}$ & $\delta^{13} \mathrm{C}$ \\
\hline & & & \\
\hline 0.300 & 17.6 & 4.18 & 0.06 \\
0.340 & 19.4 & 4.29 & 0.23 \\
0.340 & 19.4 & 4.33 & 0.16 \\
0.370 & 20.7 & 4.27 & 0.03 \\
0.400 & 22.0 & 4.16 & 0.14 \\
0.440 & 23.7 & 3.95 & 0.22 \\
0.470 & 25.1 & 3.95 & 0.14 \\
0.600 & 30.8 & 3.70 & 0.17 \\
& & &
\end{tabular}

Source. Curry and Lohmann [1983, 1985]

Species: $C$. wuellerstorfi

Depth, m Age, kyr $\quad \delta^{18} \mathrm{O} \quad \delta^{13} \mathrm{C}$

\begin{tabular}{|c|c|c|c|}
\hline \multicolumn{4}{|c|}{$\begin{array}{l}\text { Core: EN066-26 } \\
3^{\circ} \mathrm{N} 20^{\circ} \mathrm{W} \\
4745 \mathrm{~m}\end{array}$} \\
\hline 0.040 & 2.5 & 2.64 & 0.84 \\
\hline 0.100 & 6.3 & 2.67 & 0.52 \\
\hline 0.140 & 8.8 & 3.04 & 0.24 \\
\hline 0.170 & 10.7 & 3.28 & 0.51 \\
\hline 0.200 & 12.6 & 3.62 & 0.20 \\
\hline 0.240 & 15.0 & 4.19 & 0.19 \\
\hline 0.270 & 15.9 & 4.11 & 0.10 \\
\hline 0.300 & 16.9 & 4.16 & -0.16 \\
\hline 0.340 & 18.1 & 4.23 & -0.18 \\
\hline 0.370 & 19.0 & 4.03 & -0.25 \\
\hline 0.400 & 19.9 & 4.10 & -0.06 \\
\hline 0.440 & 21.1 & 4.23 & 0.10 \\
\hline 0.470 & 22.0 & 4.01 & 0.05 \\
\hline 0.500 & 22.9 & 3.97 & 0.13 \\
\hline 0.600 & 26.0 & 3.59 & 0.07 \\
\hline
\end{tabular}

Source: Curry and Lohmann [1983, 1985]

Species. C. wuellerstorfi

\begin{tabular}{llll}
\hline Depth, m Age, kyr & $\delta^{18} \mathrm{O}$ & $\delta^{13} \mathrm{C}$ \\
\hline \multicolumn{4}{l}{ Core: EN066-32 } \\
\multicolumn{2}{l}{$2^{\circ} \mathrm{N} 20^{\circ} \mathrm{W}$} \\
$5003 \mathrm{~m}$
\end{tabular}

\begin{tabular}{cccc}
\hline Depth, m & Age, kyr & $\delta^{18} \mathrm{O}$ & $\delta^{13} \mathrm{C}$ \\
\hline & & & \\
\hline 0.200 & 9.7 & 3.31 & 0.54 \\
0.240 & 11.8 & 3.46 & 0.63 \\
0.300 & 15.0 & 4.11 & 0.41 \\
0.340 & 16.1 & 4.09 & 0.04 \\
0.370 & 16.9 & 4.08 & 0.06 \\
0.400 & 17.7 & 4.05 & -0.30 \\
0.440 & 18.8 & 4.12 & -0.20 \\
0.640 & 24.2 & 3.89 & -0.19 \\
0.700 & 25.8 & 3.80 & 0.22 \\
0.740 & 26.9 & 3.73 & 0.14 \\
0.770 & 27.7 & 3.74 & 0.17 \\
& & & \\
\hline
\end{tabular}

Source: Curry and Lohmann [1983, 1985]

Species: C. wuellerstorfi

$\overline{\text { Depth, } \mathrm{m} \quad \text { Age, kyr } \quad \delta^{18} \mathrm{O} \quad \delta^{13} \mathrm{C}}$

Core: EN066-29

$2^{\circ} \mathrm{N} 20^{\circ} \mathrm{W}$

$5104 \mathrm{~m}$

$\begin{array}{rcrr}0.040 & 2.9 & 2.41 & 0.85 \\ 0.040 & 2.9 & 2.72 & 0.84 \\ 0.100 & 6.1 & 2.86 & 0.48 \\ 0.140 & 8.3 & 3.01 & 0.77 \\ 0.200 & 11.5 & 3.14 & 0.21 \\ 0.200 & 11.5 & 3.19 & 0.18 \\ 0.240 & 15.0 & 4.03 & -0.04 \\ 0.300 & 16.5 & 3.87 & -0.29 \\ 0.300 & 16.5 & 4.24 & -0.34 \\ 0.400 & 19.0 & 3.50 & -0.16 \\ 0.500 & 21.5 & 4.00 & -0.23 \\ 0.540 & 22.5 & 3.99 & 0.01 \\ 0.600 & 24.0 & 3.62 & 0.27 \\ 0.640 & 25.0 & 3.44 & 0.01 \\ 0.700 & 26.5 & 3.75 & 0.06\end{array}$

Source- Curry and Lohmann [1983, 1985]

Species $C$. wuellerstorfi

c. whellerstorf

\begin{tabular}{llll} 
Depth, $m \quad$ Age, kyr $\quad \delta^{18} \mathrm{O} \quad \delta^{13} \mathrm{C}$ \\
\hline
\end{tabular}

Core: BT4

$4^{\circ} \mathrm{S} 10^{\circ} \mathrm{E}$

$1000 \mathrm{~m}$

$\begin{array}{llll}0.050 & 0.5 & 2.57 & 0.33 \\ 0.190 & 3.2 & 2.47 & 0.43\end{array}$

Depth, m Age, kyr $\quad \delta^{18} \mathrm{O} \quad \delta^{13} \mathrm{C}$

\begin{tabular}{cccc}
\hline & & & \\
0.290 & 8.6 & 3.00 & 0.15 \\
0.390 & 9.9 & 3.08 & 0.09 \\
0.500 & 10.9 & 2.87 & 0.20 \\
0.590 & 11.4 & 2.93 & 0.03 \\
0.690 & 12.2 & 3.36 & 0.10 \\
0.790 & 13.2 & 3.46 & -0.06 \\
0.900 & 14.3 & 3.70 & 0.24 \\
0.990 & 15.2 & 3.83 & 0.19 \\
1.090 & 16.6 & 3.77 & 0.16 \\
1.190 & 18.0 & 3.49 & 0.00 \\
1.290 & 19.4 & 3.63 & 0.07 \\
1.490 & 22.2 & 3.59 & 0.02 \\
1.590 & 23.6 & 3.47 & 0.02 \\
1.690 & 25.0 & 3.30 & 0.19 \\
1.790 & 26.4 & 3.52 & 0.19 \\
1.890 & 27.7 & 3.48 & 0.01
\end{tabular}

Source- Shackleton [unpublished data] Species. Cabrcidordes spp

Depth, $m \quad$ Age, kyr $\quad \delta^{18} \mathrm{O} \quad \delta^{13} \mathrm{C}$

Core: RC13-228

$22^{\circ} \mathrm{S} 11^{\circ} \mathrm{E}$

$3204 \mathrm{~m}$

$\begin{array}{rrrr}0.000 & 0.0 & 3.19 & 0.14 \\ 0.020 & 0.3 & 2.62 & 0.44 \\ 0.070 & 0.9 & 2.58 & 0.64 \\ 0.130 & 1.7 & 2.53 & 0.75 \\ 0.180 & 2.4 & 2.51 & 0.40 \\ 0.230 & 3.1 & 2.58 & 0.49 \\ 0.320 & 4.5 & 2.63 & 0.55 \\ 0.380 & 5.4 & 2.77 & 0.59 \\ 0.430 & 6.1 & 2.75 & 0.42 \\ 0.480 & 6.9 & 2.87 & 0.27 \\ 0.520 & 7.5 & 2.70 & 0.12 \\ 0.630 & 9.0 & 3.21 & 0.05 \\ 0.730 & 9.9 & 3.54 & 0.06 \\ 0.820 & 10.7 & 3.81 & -0.15 \\ 0.880 & 11.2 & 3.82 & -0.12 \\ 0.930 & 11.6 & 3.47 & -0.25 \\ 0.980 & 12.7 & 4.22 & 0.03 \\ 1.070 & 15.0 & 4.51 & 0.09 \\ 1.130 & 15.6 & 4.33 & -0.29 \\ 1.180 & 16.1 & 4.44 & -0.06 \\ 1.200 & 16.3 & 4.34 & -0.09 \\ 1.230 & 16.6 & 4.39 & -0.02 \\ 1.270 & 17.0 & 4.50 & 0.03 \\ 1.320 & 17.6 & 4.23 & -0.14 \\ 1.430 & 18.7 & 4.18 & -0.15 \\ 1.480 & 19.2 & 4.21 & 0.00\end{array}$




\begin{tabular}{|c|c|c|c|c|c|c|c|c|c|c|c|}
\hline Depth, m & Age, kyr & $\delta^{18} \mathrm{O}$ & $\delta^{13} \mathrm{C}$ & Depth, m & Age, kyr & $\delta^{18} \mathrm{O}$ & $\delta^{13} \mathrm{C}$ & Depth, m & Age, kyr & $\delta^{18} \mathrm{O}$ & $\delta^{13} \mathrm{C}$ \\
\hline 1.500 & 19.4 & 4.12 & -0.49 & \multicolumn{4}{|c|}{ Core: MD84-527 } & \multicolumn{4}{|c|}{ Core: RC11-120 } \\
\hline 1.630 & 20.7 & 4.15 & -0.03 & \multicolumn{4}{|c|}{$44^{\circ} \mathrm{S} 51^{\circ} \mathrm{E}$} & \multicolumn{4}{|c|}{$44^{\circ} \mathrm{S} 80^{\circ} \mathrm{E}$} \\
\hline 1.680 & 21.2 & 4.12 & -0.06 & \multicolumn{4}{|l|}{$3269 \mathrm{~m}$} & \multicolumn{4}{|l|}{$3193 \mathrm{~m}$} \\
\hline 1.730 & 21.8 & 4.05 & -0.08 & & & & & & & & \\
\hline 1.820 & 22.7 & 4.16 & 0.33 & 0.050 & 0.3 & 3.09 & 0.28 & 0.050 & 0.9 & 2.92 & 0.39 \\
\hline 1.880 & 23.3 & 4.21 & 0.20 & 0.130 & 0.8 & 3.05 & 0.51 & 0.150 & 3.9 & 2.37 & 0.29 \\
\hline 1.930 & 23.8 & 3.94 & 0.09 & 0.230 & 1.4 & 3.03 & 0.19 & 0.150 & 3.9 & 2.74 & 0.61 \\
\hline 1.980 & 24.3 & 3.81 & 0.21 & 0.300 & 1.8 & 2.84 & 0.45 & 0.300 & 8.5 & 2.84 & 0.45 \\
\hline \multirow[t]{2}{*}{2.020} & 24.7 & 3.80 & 0.27 & 0.400 & $\begin{array}{l}1.0 \\
2.5\end{array}$ & $\begin{array}{l}2.04 \\
2.53\end{array}$ & 0.13 & 0.400 & 10.7 & 3.88 & 0.15 \\
\hline & & & & 0.500 & 3.1 & 2.88 & 0.23 & 0.450 & 11.4 & 3.45 & 0.12 \\
\hline \multirow{2}{*}{\multicolumn{4}{|c|}{ Source· Shackleton [unpublished data] }} & 0.530 & 3.3 & 3.17 & 0.42 & 0.600 & 14.9 & 4.52 & -0.23 \\
\hline & & & & 0.600 & 3.7 & 2.84 & 0.13 & 0.800 & 20.8 & 4.45 & -0.48 \\
\hline \multicolumn{4}{|c|}{ Species. Cabsczdozdes spp } & 0.700 & 4.3 & 3.15 & 0.37 & 0.850 & 22.2 & 4.55 & -0.32 \\
\hline & & & & 0.730 & 4.5 & 2.99 & 0.31 & 0.900 & 23.7 & 4.43 & -0.46 \\
\hline & & & & 0.800 & 4.9 & 2.84 & 0.14 & 0.950 & 25.1 & 4.36 & -0.12 \\
\hline & & & & 0.830 & 5.1 & 2.95 & 0.26 & & & & \\
\hline & & & & 0.900 & 5.5 & 2.89 & 0.07 & \multirow{2}{*}{\multicolumn{4}{|c|}{ Source: Shackleton [unpublished data] }} \\
\hline \multirow{3}{*}{ Depth, m } & \multirow{3}{*}{ Age, kyr } & \multirow{3}{*}{$\delta^{18} \mathrm{O}$} & \multirow{3}{*}{$\delta^{13} \mathrm{C}$} & 1.000 & 6.2 & 3.02 & 0.00 & & & (a) & \\
\hline & & & & 1.100 & 6.8 & 2.73 & -0.24 & & & & \\
\hline & & & & 1.130 & 7.0 & 3.19 & -0.16 & & & & \\
\hline Core: $\mathrm{RC1}$ & $3-229$ & & & 1.200 & 7.4 & 2.82 & -1.25 & & & & \\
\hline $26^{\circ} \mathrm{S} 11^{\circ} \mathrm{E}$ & & & & 1.300 & 8.0 & 2.65 & -0.18 & & & & \\
\hline $4194 \mathrm{~m}$ & & & & 1.430 & 8.7 & 3.03 & -0.18 & Depth, m & Age, kyr & $\delta^{18} \mathrm{O}$ & $\delta^{13} \mathrm{C}$ \\
\hline & & & & 1.500 & 9.0 & 3.09 & -0.11 & & & & \\
\hline 0.025 & & & & 1.600 & 9.3 & 3.21 & 0.00 & & & & \\
\hline $\begin{array}{l}0.025 \\
0.025\end{array}$ & 3.2 & 2.73 & 0.31 & 1.700 & 9.7 & 3.30 & -0.15 & Core: $\mathrm{MD}^{\prime}$ & $6-135$ & & \\
\hline $\begin{array}{l}0.025 \\
0.045\end{array}$ & 3.2 & 2.16 & 0.47 & 1.800 & 10.1 & 3.26 & -0.51 & $14^{\circ} \mathrm{N} 51^{\circ} \mathrm{E}$ & & & \\
\hline $\begin{array}{l}0.040 \\
0.065\end{array}$ & $\begin{array}{l}3.9 \\
4.6\end{array}$ & 2.73 & 0.25 & 2.100 & 11.2 & 3.42 & -0.12 & $1895 \mathrm{~m}$ & & & \\
\hline 0.085 & $\begin{array}{l}4.6 \\
5.3\end{array}$ & 2.76 & 0.35 & 2.200 & 11.6 & 3.56 & 0.01 & & & & \\
\hline 0.100 & $\begin{array}{l}5.3 \\
5.9\end{array}$ & 2.81 & 0.39 & 2.300 & 11.8 & 3.74 & -0.12 & 0.000 & 0.0 & 2.41 & -0.14 \\
\hline 0.100 & 5.9 & 2.66 & 0.27 & 2.400 & 12.1 & 3.79 & -0.40 & 0.100 & 2.1 & 2.29 & -0.17 \\
\hline 0.145 & 5.9 & 2.83 & 0.25 & 2.500 & 12.3 & 3.81 & -0.31 & 0.200 & 3.5 & 2.45 & -0.15 \\
\hline 0.200 & 7.5 & 2.67 & 0.41 & 2.600 & 12.5 & 3.96 & -0.22 & 0.300 & 4.1 & 2.64 & -0.06 \\
\hline 0.250 & 8.9 & 2.92 & 0.44 & 2.700 & 12.7 & 3.97 & -0.29 & 0.400 & 4.6 & 2.68 & -0.16 \\
\hline 0.300 & $\begin{array}{c}9.5 \\
10 ?\end{array}$ & 3.04 & 0.20 & 2.800 & 13.8 & 4.49 & -0.38 & 0.500 & 5.1 & 2.75 & -0.07 \\
\hline 0.310 & 10.2 & 2.96 & 0.19 & 2.900 & 15.0 & 4.54 & -0.35 & 0.600 & 5.6 & 2.64 & -0.10 \\
\hline $\begin{array}{l}0.310 \\
0.350\end{array}$ & 10.9 & 3.30 & 0.16 & 2.930 & 15.2 & 4.40 & -0.55 & 0.700 & 6.2 & 2.54 & -0.08 \\
\hline $\begin{array}{l}0.350 \\
0.400\end{array}$ & 12.0 & 3.61 & -0.10 & 3.000 & 15.6 & 4.28 & -0.38 & 0.800 & 6.6 & 2.52 & -0.17 \\
\hline & 12.7 & 3.65 & 0.03 & 3.020 & 15.7 & 4.62 & -0.44 & 0.900 & 6.9 & 2.64 & -0.27 \\
\hline 0.410 & 12.8 & 3.72 & -0.15 & 3.100 & 16.2 & 4.34 & -0.33 & 1.000 & 7.2 & 2.72 & -0.08 \\
\hline 0.450 & 15.0 & 4.26 & -0.47 & 3.130 & 16.4 & 4.38 & -0.77 & 1.100 & 7.6 & 2.82 & -0.10 \\
\hline 0.500 & 15.8 & 4.03 & -0.20 & 3.200 & 16.9 & 4.29 & -0.64 & 1.200 & 7.9 & 2.73 & -0.17 \\
\hline 0.550 & 16.6 & 4.07 & -0.42 & $\begin{array}{l}0.200 \\
3.300\end{array}$ & 17.5 & 4.31 & $\begin{array}{l}-0.04 \\
-0.45\end{array}$ & 1.300 & 8.2 & 2.86 & -0.26 \\
\hline 0.600 & 17.4 & 4.20 & -0.29 & $\begin{array}{l}3.500 \\
3.400\end{array}$ & 18.1 & 4.33 & $\begin{array}{l}-0.45 \\
-0.68\end{array}$ & 1.400 & 8.6 & 2.51 & -0.11 \\
\hline 0.600 & 17.4 & 4.31 & -0.52 & $\begin{array}{l}3.400 \\
3.500\end{array}$ & $\begin{array}{l}10.1 \\
18.7\end{array}$ & $\begin{array}{l}4.50 \\
4.30\end{array}$ & -0.68 & 1.500 & 9.1 & 2.62 & 0.02 \\
\hline 0.650 & 18.2 & 4.23 & -0.48 & $\begin{array}{l}3.500 \\
3.600\end{array}$ & $\begin{array}{l}10.6 \\
19.4\end{array}$ & 4.30 & -0.54 & 1.600 & 9.6 & 2.91 & -0.45 \\
\hline 0.700 & 19.0 & 4.05 & -0.20 & $\begin{array}{l}3.600 \\
3.700\end{array}$ & $\begin{array}{l}19.4 \\
20.0\end{array}$ & 4.24 & -0.80 & 1.700 & 10.2 & 3.27 & -0.61 \\
\hline 0.710 & 19.2 & 4.16 & -0.57 & $\begin{array}{l}3.700 \\
3.800\end{array}$ & 20.0 & 4.22 & -0.47 & 1.800 & 10.7 & 3.33 & -0.85 \\
\hline 0.750 & 19.8 & 4.21 & -0.33 & 3.800 & 20.6 & 4.22 & -0.47 & 1.900 & 11.3 & 3.20 & -0.20 \\
\hline 0.800 & 20.6 & 4.15 & -0.16 & 3.900 & 21.2 & 4.23 & -0.09 & 2.000 & 12.0 & 3.26 & -0.13 \\
\hline 0.900 & 22.2 & 4.04 & -0.42 & 4.000 & 21.8 & 4.32 & -0.86 & 2.100 & 13.6 & 3.93 & 0.00 \\
\hline 1.000 & 23.3 & 4.03 & -0.37 & & & & & 2.200 & 15.2 & 4.16 & -0.11 \\
\hline & & & & Source' Labey & rie et a]. [198 & & & 2.300 & 16.7 & 3.95 & -0.01 \\
\hline & & & & Species. Cabic & :adozdes spp. & & & 2.400 & 18.3 & 4.16 & -0.10 \\
\hline Source: Opp & ind Fairbank & [1987] & & & & & & 2.500 & 19.9 & 3.93 & -0.21 \\
\hline Species: $C . w$ & ellerstorfi, & kullenber & & & & & & 2.600 & 21.4 & 3.47 & -0.17 \\
\hline & & & & & & & & 2.700 & 23.0 & 3.83 & -0.20 \\
\hline
\end{tabular}




\begin{tabular}{|c|c|c|c|c|c|c|c|c|c|c|c|}
\hline Depth, m & Age, kyr & $\delta^{18} \mathrm{O}$ & $\delta^{13} \mathrm{C}$ & Depth, m & Age, kyr & $\delta^{18} \mathrm{O}$ & $\delta^{13} \mathrm{C}$ & Depth, m & Age, kyr & $\delta^{18} \mathrm{O}$ & $\delta^{13} \mathrm{C}$ \\
\hline 2.800 & 24.6 & 3.93 & -0.12 & 0.500 & 7.8 & 2.72 & 0.26 & 0.720 & 13.5 & 4.09 & -0.42 \\
\hline 2.900 & 26.2 & 3.55 & -0.24 & 0.600 & 9.6 & 3.33 & 0.14 & 0.730 & 13.6 & 4.19 & -0.26 \\
\hline \multirow[t]{2}{*}{3.000} & 27.7 & 3.65 & -0.13 & 0.700 & 11.4 & 3.32 & 0.14 & 0.750 & 13.7 & 4.24 & -0.33 \\
\hline & & & & 0.800 & 12.7 & 3.50 & 0.15 & 0.850 & 14.3 & 4.23 & -0.20 \\
\hline \multirow{3}{*}{\multicolumn{4}{|c|}{ Source Duplessy and Labeyrie [unpublished data] }} & 1.000 & 15.0 & 4.03 & -0.02 & 0.970 & 15.0 & 4.45 & -0.28 \\
\hline & & & & 1.100 & 15.5 & 3.75 & -0.04 & 1.090 & 15.8 & 4.37 & -0.20 \\
\hline Species' $C z b z c t$ & & & & 1.200 & 16.0 & 4.04 & -0.08 & 1.210 & 16.6 & 4.46 & -0.30 \\
\hline & & & & 1.300 & 16.5 & 4.08 & -0.07 & 1.330 & 17.5 & 4.25 & -0.40 \\
\hline & & & & 1.400 & 17.0 & 3.89 & -0.22 & 1.450 & 18.3 & 4.25 & -0.47 \\
\hline & & & & 1.500 & 17.6 & 4.01 & -0.15 & 1.590 & 19.3 & 4.27 & -0.47 \\
\hline Depth, m & Age, kyr & $\delta^{18} \mathrm{O}$ & $\delta^{13} \mathrm{C}$ & & & & & 1.710 & 20.2 & 4.14 & -0.43 \\
\hline & & & & & & & & 1.830 & 21.0 & 4.26 & -0.34 \\
\hline & & & & Source Duple & ssy and Labey & ine [un & iblishe & 1.950 & 21.9 & 4.39 & -0.28 \\
\hline Core: MD7 & $9-254$ & & & Species. $C_{2} b_{3}$ & adoides spp. & & & 2.070 & 22.7 & 4.06 & -0.33 \\
\hline $18^{\circ} \mathrm{S} 39^{\circ} \mathrm{E}$ & & & & & & & & 2.150 & 23.3 & 4.14 & 0.03 \\
\hline $1934 \mathrm{~m}$ & & & & & & & & 2.190 & 23.6 & 4.03 & -0.48 \\
\hline & & & & & & & & 2.310 & 24.4 & 3.76 & -0.39 \\
\hline 0.000 & 0.0 & 2.74 & 0.71 & & & & & 2.430 & 25.3 & 4.18 & -0.23 \\
\hline 0.100 & 0.5 & 2.71 & 0.62 & Depth, m & Age, kyr & $\delta^{18} \mathrm{O}$ & $\delta^{13} \mathrm{C}$ & 2.550 & 26.1 & 3.93 & -0.10 \\
\hline 0.300 & 1.5 & 2.65 & 0.66 & & & & & 2.670 & 26.9 & 3.83 & -0.25 \\
\hline 0.400 & 2.1 & 2.43 & 0.62 & & & & & & & & \\
\hline 0.700 & 5.7 & 2.59 & 0.64 & Core: TR1 & 33-31 & & & & & & \\
\hline 0.800 & 6.9 & 2.82 & 0.65 & $4^{\circ} \mathrm{S} 84^{\circ} \mathrm{W}$ & & & & Source: Shack & leton [unpublis & shed data. & \\
\hline 0.900 & 8.0 & 2.60 & 0.51 & $3210 \mathrm{~m}$ & & & & Specles. $C_{a b} b_{1}$ & csdordes spp & & \\
\hline 1.000 & 9.2 & 2.74 & 0.46 & & & & & & & & \\
\hline 1.100 & 10.4 & 3.80 & 0.30 & 0.010 & 0.8 & 2.75 & 0.11 & & & & \\
\hline 1.200 & 10.9 & 3.27 & 0.09 & 0.050 & 1.9 & 2.56 & -0.38 & & & & \\
\hline 1.300 & 11.5 & 3.19 & 0.31 & 0.070 & 3.9 & 2.97 & 0.18 & Denth m & A pe kyr & $\delta^{18} 0$ & ${ }^{13} \mathrm{C}$ \\
\hline 1.400 & 12.0 & 3.77 & 0.10 & 0.110 & 5.1 & 2.88 & 0.03 & Depth, m & Age, kyr & $\delta^{10} \mathrm{O}$ & $\delta^{10} \mathrm{C}$ \\
\hline 1.500 & 12.4 & 3.95 & 0.00 & 0.120 & 5.3 & 2.86 & -0.04 & & & & \\
\hline 1.600 & 12.7 & 3.32 & 0.08 & 0.130 & 5.6 & 2.86 & 0.02 & Cre. V98 & 304 & & \\
\hline 2.100 & 14.7 & 3.58 & 0.33 & 0.160 & 6.3 & 3.10 & 0.09 & Core: $128-$ & & & \\
\hline 2.200 & 15.1 & 4.22 & 0.08 & 0.190 & 7.0 & 3.37 & 0.11 & $29^{\circ} \mathrm{N} 134^{\circ} \mathrm{E}$ & & & \\
\hline 2.300 & 15.8 & 4.19 & -0.02 & 0.200 & 7.3 & 2.81 & 0.24 & $2942 \mathrm{~m}$ & & & \\
\hline 3.100 & 21.3 & 3.95 & 0.27 & 0.230 & 8.0 & 3.05 & -0.11 & & & & \\
\hline 3.400 & 23.4 & 3.77 & 0.08 & 0.240 & 8.3 & 2.98 & -0.09 & 0.000 & 0.0 & 2.69 & 0.11 \\
\hline 3.500 & 24.1 & 3.66 & 0.39 & 0.250 & 8.5 & 3.04 & -0.08 & 0.040 & 1.4 & 2.67 & 0.35 \\
\hline & & & & 0.260 & 8.7 & 2.69 & -0.40 & 0.120 & 4.1 & 2.69 & 0.37 \\
\hline & & & & 0.260 & 8.7 & 3.54 & -0.26 & 0.160 & 5.5 & 2.59 & 0.20 \\
\hline Source Duples & $y$ and Labeyr & te [unpub & lished data] & 0.270 & $\begin{array}{l}0.1 \\
8.9\end{array}$ & $\begin{array}{l}.044 \\
329\end{array}$ & $\begin{array}{r}-0.20 \\
-0.30\end{array}$ & 0.160 & 5.5 & 2.67 & 0.28 \\
\hline Species $\quad C_{\imath} b r c u$ & dosdes spp. & & & 0.310 & $\begin{array}{l}0.9 \\
9.7\end{array}$ & $\begin{array}{l}3.22 \\
3.43\end{array}$ & $\begin{array}{l}-0.30 \\
-0.32\end{array}$ & 0.200 & 6.9 & 2.80 & 0.26 \\
\hline & & & & 0.320 & 9.9 & 3.13 & $\begin{array}{l}-0.32 \\
-0.04\end{array}$ & 0.400 & 13.0 & 3.71 & -0.12 \\
\hline & & & & 0.350 & 10.5 & 3.05 & $\begin{array}{l}-0.04 \\
-0.19\end{array}$ & 0.440 & 13.7 & 4.22 & -0.02 \\
\hline & & & & 0.360 & 10.7 & 3.39 & $\begin{array}{l}-0.19 \\
-0.07\end{array}$ & 0.480 & 13.8 & 3.85 & -0.16 \\
\hline & & & & 0.370 & 10.9 & 3.65 & $\begin{array}{l}-0.07 \\
-0.10\end{array}$ & 0.760 & 14.6 & 4.15 & -0.11 \\
\hline Depth, m & Age, kyr & $\delta^{18} \mathrm{O}$ & $\delta^{13} \mathrm{C}$ & 0.400 & $\begin{array}{l}10.9 \\
11.5\end{array}$ & $\begin{array}{l}5.00 \\
3.36\end{array}$ & $\begin{array}{l}-0.10 \\
-0.11\end{array}$ & 0.900 & 15.3 & 4.42 & 0.06 \\
\hline & & & & $\begin{array}{l}0.400 \\
0.430\end{array}$ & $\begin{array}{l}11.0 \\
11.8\end{array}$ & $\begin{array}{l}0.00 \\
3.90\end{array}$ & $\begin{array}{r}-0.11 \\
0.04\end{array}$ & 1.000 & 17.0 & 4.36 & -0.01 \\
\hline & & & & 0.440 & 11.9 & 3.92 & 0.04 & 1.100 & 18.7 & 4.33 & 0.16 \\
\hline Core: MDT & $6-125$ & & & 0.490 & 12.2 & 3.39 & $\begin{array}{l}0.11 \\
0.00\end{array}$ & 1.300 & 22.2 & 4.12 & 0.05 \\
\hline $8^{\circ} \mathrm{N} 75^{\circ} \mathrm{E}$ & & & & 0.510 & 12.3 & 3.80 & $\begin{array}{r}0.00 \\
-0.02\end{array}$ & 1.600 & 27.3 & 3.77 & -0.08 \\
\hline $1878 \mathrm{~m}$ & & & & 0.520 & 12.3 & 3.98 & $\begin{array}{r}-0.02 \\
0.14\end{array}$ & 1.900 & 32.4 & 3.55 & 0.11 \\
\hline & & & & 0.550 & 12.5 & 3.48 & -0.18 & & & & \\
\hline 0.000 & 0.0 & 2.62 & 0.29 & 0.550 & 12.5 & 3.80 & -0.01 & Source' Shack & leton [unpublis & hed data? & \\
\hline 0.100 & 1.2 & 2.85 & 0.21 & 0.590 & 12.7 & 4.03 & -0.19 & Species: $C_{2} b 3 c$ & crdosdes spp & & \\
\hline 0.200 & 2.5 & 2.52 & 0.17 & 0.590 & 12.7 & 3.79 & -0.45 & & & & \\
\hline 0.300 & 4.3 & 2.65 & 0.26 & 0.610 & 12.9 & 4.02 & 0.00 & & & & \\
\hline 0.400 & 6.1 & 2.95 & 0.12 & 0.710 & 13.4 & 4.02 & -0.11 & & & & \\
\hline
\end{tabular}


$\overline{\text { Depth, } \mathrm{m} \quad \text { Age, kyr } \quad \delta^{18} \mathrm{O} \quad \delta^{13} \mathrm{C}}$

Core: KNR73-4-3
$0^{\circ} 106^{\circ} \mathrm{W}$
$3606 \mathrm{~m}$

\begin{tabular}{|c|c|c|c|}
\hline 0.100 & 0.7 & 2.58 & 0.29 \\
\hline 0.135 & 1.5 & 2.46 & 0.29 \\
\hline 0.170 & 2.2 & 2.31 & 0.28 \\
\hline 0.200 & 3.2 & 2.54 & 0.16 \\
\hline 0.270 & 5.3 & 2.57 & 0.01 \\
\hline 0.300 & 6.2 & 2.64 & 0.22 \\
\hline 0.335 & 7.3 & 2.81 & 0.97 \\
\hline 0.370 & 8.4 & 2.57 & 0.30 \\
\hline 0.400 & 8.9 & 3.13 & -0.11 \\
\hline 0.470 & 9.8 & 2.99 & 0.08 \\
\hline 0.500 & 10.2 & 3.04 & 0.01 \\
\hline 0.535 & 10.7 & 3.29 & -0.09 \\
\hline 0.600 & 11.5 & 3.12 & -0.13 \\
\hline 0.635 & 12.1 & 3.37 & -0.39 \\
\hline 0.670 & 14.0 & 3.84 & -0.11 \\
\hline 0.700 & 15.3 & 4.01 & -0.23 \\
\hline 0.735 & 16.1 & 4.00 & -0.22 \\
\hline 0.770 & 16.9 & 3.80 & -0.20 \\
\hline 0.800 & 17.6 & 3.59 & -0.37 \\
\hline 0.835 & 18.3 & 3.72 & -0.21 \\
\hline 0.900 & 19.8 & 3.86 & -0.10 \\
\hline 0.950 & 21.0 & 4.01 & -0.19 \\
\hline 1.035 & 22.9 & 3.78 & 0.01 \\
\hline 1.070 & 23.7 & 3.56 & -0.11 \\
\hline 1.100 & 24.4 & 3.67 & 0.09 \\
\hline 1.135 & 25.2 & 3.68 & 0.03 \\
\hline 1.170 & 26.0 & 3.56 & 0.19 \\
\hline 1.200 & 26.7 & 3.65 & 0.09 \\
\hline 1.270 & 28.3 & 3.85 & 0.03 \\
\hline 1.300 & 28.9 & 3.55 & 0.01 \\
\hline 1.335 & 29.7 & 3.43 & 0.19 \\
\hline
\end{tabular}

Source. Boyle and Keigwin [1985/86]

Species. C. wuellerstorfi, C. kullenbergs
Depth, m Age, kyr $\quad \delta^{18} \mathrm{O} \quad \delta^{13} \mathrm{C}$

Depth, m Age, kyr $\quad \delta^{18} \mathrm{O} \quad \delta^{13} \mathrm{C}$

Core: V19-30

$3^{\circ} \mathrm{S} 83^{\circ} \mathrm{W}$

$3091 \mathrm{~m}$

Core: V35-05

$7^{\circ} \mathrm{N} 112^{\circ} \mathrm{E}$

$1950 \mathrm{~m}$

\begin{tabular}{rrrr}
0.320 & 4.1 & 2.66 & -0.09 \\
0.360 & 4.6 & 2.85 & 0.03 \\
0.380 & 4.9 & 2.95 & 0.04 \\
0.480 & 6.2 & 2.84 & 0.08 \\
0.500 & 6.5 & 2.67 & -0.03 \\
0.560 & 7.2 & 3.07 & 0.00 \\
0.600 & 7.7 & 3.22 & -0.01 \\
0.630 & 8.1 & 3.41 & 0.03 \\
1.180 & 15.1 & 4.47 & -0.39 \\
1.200 & 15.3 & 4.36 & -0.26 \\
1.230 & 15.4 & 4.42 & -0.33 \\
1.270 & 15.7 & 4.20 & -0.44 \\
1.300 & 15.9 & 4.35 & -0.41 \\
1.320 & 16.0 & 4.26 & -0.19 \\
1.350 & 16.2 & 4.24 & -0.53 \\
1.390 & 16.4 & 4.27 & -0.33 \\
1.410 & 16.6 & 4.28 & -0.47 \\
1.440 & 16.7 & 4.12 & -0.56 \\
1.480 & 17.0 & 4.36 & -0.51 \\
1.520 & 17.2 & 4.26 & -0.70 \\
\hline
\end{tabular}

Source. Shackelton [unpublished data]

0.020

0.050

0.070

0.125

0.125

0.125

0.650

0.725

0.900

0.925

0.975

1.075

1.125

1.175

1.230

1.250

1.325

1.375

1.425

1.550

2.475

2.475

2.775

3.090

$\begin{array}{lll}0.2 & 2.68 & -0.02\end{array}$

$\begin{array}{lll}0.4 & 2.32 & 0.02\end{array}$

$\begin{array}{lll}0.6 & 2.27 & -0.02\end{array}$

$\begin{array}{lll}1.1 & 2.46 & 0.11\end{array}$

$\begin{array}{lll}1.1 & 2.41 & 0.02\end{array}$

$\begin{array}{lll}1.1 & 2.34 & 0.01\end{array}$

$\begin{array}{lll}5.5 & 2.43 & 0.01\end{array}$

$\begin{array}{lll}6.2 & 2.46 & -0.15\end{array}$

$\begin{array}{lll}7.7 & 2.60 & -0.10\end{array}$

$\begin{array}{lll}7.9 & 2.71 & 0.01\end{array}$

$\begin{array}{lll}8.3 & 2.42 & -0.25\end{array}$

$\begin{array}{lll}9.1 & 2.85 & -0.18\end{array}$

$\begin{array}{lll}9.4 & 2.75 & -0.20\end{array}$

$\begin{array}{lll}9.7 & 2.60 & -0.37\end{array}$

$\begin{array}{lll}10.1 & 2.89 & 0.00\end{array}$

$\begin{array}{lll}10.2 & 2.90 & -0.24\end{array}$

$\begin{array}{lll}10.7 & 2.87 & -0.35\end{array}$

$\begin{array}{lll}11.1 & 3.29 & -0.22\end{array}$

$\begin{array}{lll}11.4 & 3.05 & -0.19\end{array}$

$\begin{array}{lll}12.0 & 3.25 & -0.14\end{array}$

$\begin{array}{lll}15.2 & 3.87 & -0.33\end{array}$

$\begin{array}{lll}15.2 & 3.92 & -0.39\end{array}$

Species: Cibrcidordes spp.
Source. Oppo and Fairbanks [1987]

Species. C. wuellerstorfi, C. kullenbergı 
Acknowledgments. This paper was presented during the Deep Water Paleoceanography Symposium at the Second International Conference on Paleoceanography at Woods Hole, September 1986. We thank all of the contributors to that session for their cooperation and discussions. We especially than E. Boyle, R. Fairbanks, L. Keigwin and D. Oppo for sharing with us their preprints and unpublished data. This research was supported by NSF grants OCE85-11014 and OCE83-9124 to W.B.C. J.-C. Duplessy and L. D. Labeyrie are supported by CNRS, CEA, TAAF, INEDC and program $\mathrm{CO}_{2}$-PIREN. This is Woods Hole Oceanographic Institution Contribution 6813 and CFR contribution 949.

\section{REFERENCES}

Belanger, P.E., W.B. Curry, and R.K. Matthews, Core-top evaluation of benthic foraminiferal isotopic ratios for paleoceanographic interpretation, Palaeogeogr. Palaeoclimatol. Palaeoecol., 39, 205-220, 1981.

Boyle, E.A., Paired carbon isotope and cadmium data from benthic foraminifera: Implications for changes in oceanic phosphorous, oceanic circulation, and atmospheric carbon dioxide, Geochım. Cosmochim. Acla, 50, 265-276, 1986.

Boyle, E. A. and L. D. Keigwin, Deep circulation of the North Atlantic over the last 200,000 years: Geochemical evidence, Science, 218, 784-787, 1982.

Boyle, E.A., and L.D. Keigwin, Comparison of Atlantic and Pacific paleochemical records for the last 215,000 years: Changes in deep ocean circulation and chemical inventories, Earth and Planetary Science Letters, 76, 135-150, 1985/86.

Boyle, E.A., and L.D. Keigwin, Glacial North Atlantic hydrography and atmospheric carbon dioxide, EOS Trans. AGU, 67, 868-869, 1986.

Broecker, W.S., Geochemical tracers and ocean circulation, in Evolution of Physical Oceanography, edited by B.A. Warren and C. Wunsch, pp. 434-460, MIT Press, Cambridge, Mass., 1981.

Broecker, W. S., Glacial to interglacial changes in ocean chemistry, Prog. in Oceanogr., 11, 151-197, 1982.

Broecker, W. S., and T.-H. Peng, Tracers in the Sea, 690 pp., Eldigio Press, New York, 1982.

Chung, Y, and H. Craig, Radium-226 in the eastern equatorial Pacific, Earth Planet. Sci. Lett., 17, 306-318, 1973.

Cofer-Shabica, N.B., and L.C. Peterson, Carbon isotope evidence for an $\mathrm{O}_{2}$-rich deep water in the eastern Caribbean Sea, Geol. Soc. Am. Abstr. Programs, 17, $567,1986$.

Corliss, B.H., Microhabitats of benthic foraminifera within deep-sea sediments, Nature, 314, 435-438, 1985.

Curry, W.B., and G.P. Lohmann, Carbon isotopic changes in benthic foraminifera from the western South Atlantic: Reconstruction of glacial abyssal circulation patterns, Quat. Res., 18, 218-235, 1982.

Curry, W. B., and G. P. Lohmann, Reduced advection into Atlantic Ocean deep eastern basins during last glaciation maximum, Nature, 306, 577-580, 1983.

Curry, W. B., and G. P. Lohmann, Carbon deposition rates and deep water residence time in the equatorial Atlantic Ocean throughout the last 160,000 years, in The Carbon Cycle and Atmospheric $\mathrm{CO}_{2}$ : Natural Varzations Archean to Recent, Geophys. Monogr. Ser., vol. 32, edited by E. Sundquist and W. Broecker, 285-301, AGU, Washington, D.C., 1985.

Duplessy, J.C., North Atlantic deep water circulation during the last climatic cycle, Bull. Inst. Geol. Bassin d'Aquitaine, 31, 379-391, 1982.

Duplessy, J.C., J. Moyes, and C. Pujol, Deep water formation in the North Atlantic Ocean during the last ice age, Nature, 286, 479-482, 1980.

Duplessy, J.C., N.J. Shackleton, R.K. Matthews, W. Prell, W.F. Ruddiman, M. Caralp, and C. Hendy, ${ }^{13} \mathrm{C}$ record of benthic foraminifera in the last interglacial ocean: Implications for the carbon cycle and the global deep water circulation, Quat. Res., 21, 225-243, 1984.

Duplessy, J.-C., N. J. Shackleton, R. G. Fairbanks, L. D. Labeyrie, D. Oppo, and N. Kallel, Deep water source variations during the last climatic cycle and their impact on the global deep water circulation, this issue.

Graham, D.W., B.H. Corliss, M.L. Bender, and L.D. Keigwin, Carbon and oxygen isotopic disequilibria of Recent deep-sea foraminifera, Mar. Micropaleontol., 6, 483-497, 1981.

Imbrie, J., J. D. Hays, D. G. Martinson, A. McIntyre, A. C. Mix, J.J. Morley, N. G. Pisias, W. L. Prell, and N. Shackleton, The orbital theory of Pleistocene climate: Support from a revised chronology of the marine $\delta^{18} \mathrm{O}$ record, in Milankovitch and Climate, edited by A. Berger et al., pp. 269-305, D. Riedel, Hingham, Mass., 1984.

Keigwin, L., Stable isotope stratigraphy and paleoceanography of Sites 502 and 503, Initial Rep. Deep Sea Drill. Proj., 68, 445-453, 1982.

Kroopnick, P.M., The dissolved $\mathrm{O}_{2}-\mathrm{CO}_{2}{ }^{-13} \mathrm{C}$ system in the eastern equatorial Pacific, Deep Sea Res., 21, 211-227, 1974.

Kroopnick, P.M., The distribution of ${ }^{13} \mathrm{C}$ in the Atlantic Ocean, Earth Planet. Sci. Lett., 49, 469-484, 1980.

Kroopnick, P.M., The distribution of ${ }^{13} \mathrm{C}$ of $\Sigma \mathrm{CO}_{2}$ in the world oceans, Deep Sea Res., 32, 57-84, 1985.

Labeyrie, L.D., J.J. Pichon, M. Labracherie, P. Ippolito, J. Duprat, and J.C. Duplessy, Melting history of Antarctica during the past 60,000 years, Nature, 322, 701-706, 1986.

Labeyrie, L. D., J. C. Duplessy, and P.L. Blanc, Variations in mode of formation and temperature of oceanic deep waters over the past 125,000 years, Nature, 327, 477-482, 1987.

Mix, A., and R.G. Fairbanks, North Atlantic surface-ocean control of Pleistocene deep-ocean circulation, Earth Planet. Sci. Lett., 73, 231-243, 1985.

Oppo, D.W, and R.G. Fairbanks, Variability in the deep and intermediate water circulation of the Atlantic Ocean during the past 25,000 years: Northern hemisphere modulation of the Southern Ocean, Earth Planet. Sci. Lett., 86, 1-15, 1987. 
Peng, T.H., W.S. Broecker, G. Kipphut, and N. Shackleton, Benthic mixing in deep sea cores by ${ }^{14} \mathrm{C}$ dating and its implications regarding climate stratigraphy and the fate of fossil fuel $\mathrm{CO}_{2}$, in Fate of Fossil Fuel $\mathrm{CO}_{2}$ in the Oceans, edited by N. R. Andersen and A. Malahoff, pp. 355-373, Plenum, New York, 1977.

Pisias, N.G., Geologic time series from deep-sea sediments: Time scales and distortion by bioturbation, Mar. Geol., 51, 99-113, 1983.

Rubinson, M., and R.N. Clayton, Carbon-13 fractionation between aragonite and calcite, Geochim. Cosmochim. Acta, 33, 997-1002, 1969.

Shackleton, N.J., The oxygen isotope stratigraphic record of the Late Pleistocene, Philos. Trans. R. Soc. London Ser. B., 280, 169-182, 1977a.

Shackleton, N. J., Tropical rainforest history and the equatorial Pacific carbonate dissolution cycles, in Fate of Fossil Fuel $\mathrm{CO}_{2}$ in the Oceans, edited by N. R. Andersen and A. Malahoff, pp. 401-427, Plenum, New York, 1977b.

Shackleton, N.J., and N. D. Opdyke, Oxygen isotope and paleomagnetic stratigraphy of equatorial Pacific core V28-238: oxygen isotope temperatures and ice volumes on a $10^{5}$ year and $10^{6}$ year scale, Quat. Res., 3, 39-55, 1973.

Shackleton, N. J., and N. G. Pisias, Atmospheric carbon dioxide, orbital forcing, and climate, in The Carbon Cycle and Atmospheric $\mathrm{CO}_{2}$ : Natural Variations Archean to Recent, Geophys. Monogr. Ser., vol. 32, edited by E. Sundquist and W. Broecker, 303-317, AGU, Washington, D.C., 1985.

Shackleton, N.J., J. Imbrie, and M.A. Hall, Oxygen and carbon isotope record of East Pacific core V19-30: Implications for the formation of deep water in the Late Pleistocene North Atlantic, Earth Planet. Sci. Lett., 65, 233-244, 1983a.

Shackleton, N. J., M. A. Hall, J. Line, and C. Shuxi, Carbon isotope data from core V19-30 confirm reduced carbon dioxide concentration in the ice age atmosphere, Nature, 306, 319-322, 1983b.

Woodruff, F., S.M. Savin, and R.G. Douglas, Biological fractionation of oxygen and carbon isotopes by Recent benthic foraminifera, Mar. Micropaleontol., 5, 3-11, 1980.

Woodruff, F., S.M. Savin, and R.G. Douglas, Miocene stable isotope record: A detailed deep Pacific Ocean study and its paleoclimatic implications, Science, 212, 665-668, 1981.

Worthington, L.V., The water masses of the World Ocean: Some results of a fine-scale census, in Evolution of Physical Oceanography, edited by B.A. Warren and C. Wunsch, pp. 42-69, MIT Press, Cambridge, Mass., 1981.

Zahn, R., K. Winn, and M. Sarnthein, Benthic foraminiferal $\delta^{13} \mathrm{C}$ and accumulation rates of organic carbon: Uvigerina peregrina group and $C$. wuellerstorfi, Paleoceanography, 1, 27-42, 1986.

Zahn, R., and M. Sarnthein, Benthos isotopic evidence for changes of the Mediterranean outflow over the last 30,000 years, Abstracts with Programs, paper presented at the Second International Conference on Paleoceanography, Woods Hole Oceanographic Institution, Woods Hole, Mass., 1986.

W. B. Curry, Department of Geology and Geophysics, Woods Hole Oceanographic Institution, Woods Hole, MA 02543

J. C. Duplessy and L. D. Labeyrie, Centre des Faibles Radioactivites, Laboratoire Mixte CNRS/CEA, Domaine du CNRS, 91190 Gif-sur-Yvette, France

N. J. Shackleton, Godwin Laboratory for Quaternary Research, Free School Lane, Cambridge, CB2 3RS UK, England

(Received December 23, 1987; revised April 18, 1988; accepted April 22, 1988.) 